\title{
第55回日本衛生学会総会座長のまとめ
}

\author{
学会長 野 村 茂
}

101 103（88～90頁）座長 庴畑宫雄（九州大）

101 : 本題はヒト肺中のペンソ(a)ピレンの分析法を 検討し，実際に応用し，11例について湘定結果を $\mathrm{ng}$ 単 位て報告したものである。ng 単位の極めて微量であっ ても Bapが湘定可能となり，これは大気污染等との関 連において，応用されうるものであろう。分析方法につ いて䨘疑があった。

102 ：発表者らは，発癌性多環芳香族化合物の代铸は， アルコール十低糖質食により影篭されないが，発癌性二 トロソ化合物 (DMN，DEN)の代㓔は大いに高進する事 を既に観察し，今回は変異原性，肝毒性に及ほす影㰾に つき報告した。アルコール十低糖筫食のラットの肝 S一 9 は, DMN とDENの変異原性を高めた。GOT, GPT を指標とした肝毒性も若干の上昇をみた。

103 : マウスに石綿および無機粉塺 $\left(\mathrm{SiO}_{2}, \mathrm{AS}_{2} \mathrm{O}_{3}\right)$ を 胸腔内投与し，発癌性を検討した。本実験では石綿投与 による中皮腫の発生はみられなかったが，石綿，無機粉 歴投与群て，肺腺腫，腺癌の発生をみた。なおコントロ ール群のとり方につき質疑があった。

104 107（91～94頁）座長 大久保利晃（産業医大） 104 ：慈恵医大の小池らはコーヒーのがん原性に関す る動物実験で有意な増加は認められなかったと報告し た。これに対し, 名古屋市大の大野から最近の疫学的研 究では陰性の報告が多くなっているとのコメントがあっ た。コーヒーの一般生活への普及度からみて今後慎重に 検討が続けられるべきである。

105 : 北海道大の斎藤らは活性酸索が腫湯の発育に及

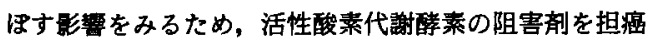
ラットに投与したところ, 生存期間の短縮を認めたと報 告した。

106 ：久留米大の富田らは $\beta$ 一カロチンが腫瘍兔疫を 賦活化することを確かめ，それに関与するリンパ球がキ ラーT細胞系であると推定した。石西（九州大）からの 発がんメカニズムの中でどの点に免疫機序が作用するか との質問に対しイニシエーション後の発育過程の極く
早い時期に関与するのではないかとの見解が示された。 107：国立公衆衛生院の箕輪らは水道水の塩素処理に よって生ずるトリハロメタンの影響を検証するために， 市町別に過去の水道水中の有機物質量と各種死因別死亡 との関係を解析したが，関西における肝硬変にのみ正の 関係が認められた。原（関西医大）から人口移動の影響 がなお否定しきれないとの意見が出された。重要な問題 なので後さらに検討されることが期待される。

108～111（95～98頁） 座長 加美山茂利（秋田大） 108，109： ${ }^{32} \mathrm{P}$ ーラペル化 DNA を用いて種々の化学 物質との反応性を調べ，発癌作用を予知するスクリーニ ングを確立しようとする意欲的なとりくみであり，108 ではジメチル硫酸などのアルキル化用を，109ではクロ ム化合物など無機化合物を取り扱っている。これら化合 物をDNA と反応させたのち，ピペリジン処理，または $\mathrm{H}_{2} \mathrm{O}_{2}$ によってヌクレオチドに分解し，電気泳動法など で分画し，塩基との結合状況をみている。北海道大の斎 藤(健)は $\mathrm{Cr}$ と $\mathrm{H}_{2} \mathrm{O}_{2}$ との混合によるDNAの切断は $\mathrm{OH}$ ラジカルによるものか，塩基との結合が原因かを質 問したが，反応中間産物からみて前者と考えられるとの ことであった。また，山口（産業医大）は本反忘が変異 原試験に比べ特徵的な点を質問したが，変異原性試験は 結果の現象をみているのに対し，本法は発滧物質の作用 メカニスムを解明できる点が有利であるとの回答がなさ れた。

110 ：標題中の “稘害修復活性”を “傷客感受性” と訂 正する旨の申し入れがあった。DNAの紫外線による傷 害のモデルとして 4NQOが使用された理由につき, 富 田（久留米大）より質問があり，マスを対象とした場合， より単純な方法が指標として利用できるかどうかを検討 したものとの答えであった。

111 ：ヒト白血球を EBウイルスで幼弱化し, $\mathrm{AHH}$ 誘導能を飛唯的に高めることができたというきれいな成 結が示された。富田（久留米大）は対象者の性状につい て質問したのに対し，大気污染の少ない地区に住む2才 
から50才の女性とのことであった。また，水野(秋田大) はHBV とPHA との幼若化率の割合, 白血球の系など について筫問したが，後者については 2 か月ほど培咅を つづけて確立された系であるとの回答でった。以上の 4 題を通じ，がん疫学が益々biochemical epidemiology の色彩をつよめて来ていることが感じられ, multi・ disciplinary な研究態勢の確立の必要性が痛感された。

112 115（99〜102頁）座長 标永咗民（愛知県がん センター)

112 : 山口ら (産業医大) は数学モデルを用いて年齢別 の潜在胃がん有病率を推定した。用いた資料は地域がん 登録資料に基づく年齢階級別胃がん罹患率々全国の胃が ん症例の胃がんの直径の分布である。その結果, 胃がん の倍加時間を $6 \sim 8$ ケ月と仮定した場合に直径 $1 \mathrm{~cm}$ 以 上の胃の潜在がんの推定有病率と集団検診で発見される 胃がんの率（有病率に相当）によく合致することがわか った。

113 ：徐(筑波大) らはわが国の悪性新生物の推移傾向 とタバコの消費量の時間的関係を調へた。その結果, 肺 がん死亡率の推移傾向はタバコ消費量の推移傾向とよく 合致していることがわかった。

114 : 島田ら(秋田大)は世界20ヶ国の全がんと胃がん, 乳がんの訂正死亡率と食物供給量との関係を解析した。 その結果, 穀類, 豆類は全がん死亡率と有意の負相関を 示し, 砂糖, 肉類, 卵類, 牛乳・乳製品は有意の正相関 を示すことを明らかにした。これらの相関はがん死亡率 をより過去の食物供給量と結びつけた場合に強くなるこ

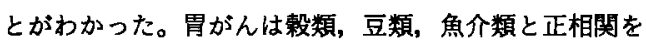
示し, 動物性食品と負の相関を示すこと, 乳がんでは胃 がんと逆の関係を示すことがわかった。

115 : 加美山ら（秋田大）山秋田県, 山形県, 長野県, 三重県の 4 地区で過去から現在に至る食物の摄取状況を 調へ, 変異原性陽性化食品と陰性化食品の性・年龆別 年代別の推移を調へた。その結果, 陰性化食品の摄取が 多いところでは胃がんの死亡率が低く，陰性化食品の摂 取が少なく，陽性化食品の摄取が多いところでは胃がん の死亡率が高いことがわかった。

\section{6〜118（103〜105頁）座長 江崎㞗次（福岡大）}

116 : 沖縄でよく摂取されている植物の抗癌作用につ いての文献調查や、これら飲食植物のビタミンA・Cの 含有量を測定している。数種の植物には抗癌作用がある
が,これら植物のビタミンA・C量や, 県内のビタミン $\mathrm{A} \cdot \mathrm{C}$ の摄取状況からみて, ビタミンが沖縄県の消化器 癌を顥著に低下させている主因とは考え難いと報告。な お抗癌作用についての討論がなされた。

117 ：セブンデー・アドベンチストは, 一般人に比して 全死亡, 脳血管疾患死亡が男女共低く, 墨性新生物死亡 は男のみ低い。このことは梀煙の影響が考えられるが， 莱食主義の影警もうかがえると報告。平山（国立がんセ ンター）加自分の研究でもほほ同じ結果を得ており， 非喫煙者を standard としても，なお低率である旨の追 加がなされた。

$118: 10$ 年間を 2 期に分け, 県内市町村別, 保健所別 の悪性新生物死亡の変化をみている。部位によって前 期, 後期で地域分布に変化がみられたもの, 安定したも のがあることを指摘し，子宮癌検診受診率と子宮癌死亡 との関連についても言及した。SMRを基にして分布地 図を作成することについて, 人口 sizeや地域の分け方 など若干の討論・追加発言があった。

119 122（106〜109頁）座長 久道 茂（東北大）

106〜109：4 題とも癌発生要因の仮説を抽出あるいは 推定することを目的とする記述疫学的研究である。特 に, 部位別癌死亡率の地域分布, 地域像を示す SMRの 地図上ての表現の仕方, あるいはその地図の理解の仕方 にいろいろ問題があることなどが指摘された。

120：それらの問題を解決する一方法としての試みて ある。すなわち, 従来の SMR ( 5 段階) で地図上の癌頻 度をみると, 散在しているようにみえる高率地域が, 隣 接する類似地域を順次まとめてゆく方法を用いると, 散 在するバラツキが修正され地域集稓性がより明らかにな るというものである。有用な方法であろう。

121：日本では少ない上額洞がんについての調查をし たもので, 府県別上額洞がん死亡率と産業別従事者数割 合との相関をみたものて，諸外国でいわれているように 木材，木製品業従事者割合と有意の正相関がみられたと の報告である。今後の分析疫学的研究が必要であろう。

122 : 最も対論の多かったもので, 乳がんの要因とし ての出生李節が関与しているかもしれないとする演者の 考え方に，疑問を感じる質問である。演者のこの研究で の仮説設定は, 釈癌の initiationとして出生前後の exposure があるかもしれない,つまり, 出生前後の季 節によってウイルスなどの流行現象が影稫しているかも しれないとするものであった。 
123 125（110～112頁）座長 河野倿一（金沢医大） 123：吉村（産業医大）らは放影研で追跡している8万 人の固定集団を用いてコホート内症例対照研究を行い, 女子若年者胃癌のリスクが初回出産年齢の高い群が低い 群にくらべて有意に低いことを報告した。平山から学歷 との関係について質問があり，演者は有意差は認められ なかったと答えた。

124 : 山本 (新潟大) は胆道がんと米の収獲量との間に 高い相関のあることに着目し，米の収隻量と関連する水 田土境の性質および農薬使用量と胆道がん死亡率との関 係について疫学的に追求し, 黄色土又は灰色低地土割合 と胆道がんSMR との間に負の，グライ土割合との間に 正の相関を認め, またいくつかの農薬出荷量と男の胆道 がんSMR との間に有意の相関のあることを報告した。

125 : 岡本 (鳥取大) らは, 鳥取県米子市のがん登録で 把握されたがん死亡者を発端者としてがんの家族集筫性 について模討し，がんの家埃集程性が考えられること， 特に，女のがん死亡者の家族の女に集積性が高いことを 報告した。これに対し，平山より個々の部位別にはどう かとの質問があったが，例数が少ないため個別のがんの 家族集積性は明らかにされなかった。

126～128（113～115頁） 座長 吉村健清（産業医大） 126 ：石川県 1 農村地域におふいて実施された胃集団検 診の成績が述べられ，その地区の胃癌死亡率の低下との 関連について議論された。地域住民の $10 \%$ 以下しか受診 していない現在の胃集団検診がどのような効果をあげて いるか考える基礎资料として重要であるとの指摘がなさ れた。

127 ：ある部位の癌の罹患者は, 他の部位の癌のリス クも高まるか否かを検討する目的で，予後がよいといわ れる甲状腺疪の手術症例の死亡が調査され, 胃癌, 結腸 癌, 直腸癌の過剩死亡の傾向が認められたことが報告さ れた。方法論的に甲状腺癌死亡を除いて検討を加えたら どのような結果になるか今後の研究を期待したい。

128 ：大腸癌を例にとり，生存率について方法論的に 険討した結果が報告された。大腸癌患者が大腸癌で死亡 するまでにどの程度生存するかを検討する上で，累積生 存率, 相対生存率, Cox の回帰分析を用いた方法につ いてその長所, 短所が議論された。方法論的に重要な問 題であるのて，更に研究が望まれる。

129 133（352 356頁） 座長 安西 定（昭和大） 129 : ベイズ型モデルによるコウホート分析（中村ら）
として, 従来のコウホート分析の難点である加柃変化, 時勢影響，コウホートによる違い等を克服するために， パラメータの漸進的変化の条件を取り込んだベイズ型モ デルを提案したものである。また，実際にこのモデルを 適用して喫煙者率データの適用結果を紹介した。

この中村らの発表について会場の丹後からこのモデル は実態をどの程度把えられるのかとの疑問がだされ両者 の間で討論がかわされたが時間切れとなったことは残念 でった。

130：那須らの発表は，この中村らのべイズ型モデル を応用して乳菌う蝕のコウホート分析を行ったものであ る。この結果, 歯種によって時代, 年齢, コウホート効 果ともに差が認められこのモデルの有用性を立証したと の発表があった。

131 : 丹後らは人口動態統計に基づく年齢, 時代, コ ウホート効果の新しい推定法として, 前の中村らのべイ ズ型モデルによるコウホート分析とは異なったモデルを 提案し，この有奻性を肝硬変死亡の変遷に適用して，そ の結果を発表したものである。この丹後らのモデルは， コウホート効果が重複せず，しかも三つの効果の時間幅 を等しくし，かつ最小の乗解が一意に定まるモテルとし て提案されたものである。前の発表者の中村との間で, 両モデルをめくっっての討論があったが, 内容が複雑で短 時間ではむりであった。

132：わが国の肺がん死亡率の経年的変化を観察する 目的で, 従来 2 次元表現であったが，今回，3 次元表現 による綎断的分析として，その結果を発表したものであ った。SAS/GRAPH を使用して年次, 地域, 死亡率に よる 3 次元表現が試みられており興味深いものであっ た。会場からも直観的に容易に判別しうるように工夫 を,との希望が出されていた。

133 : 主要死因別の SMR の時間推移の特徵を背景因 子との関連で視覚的に観察する為の方法として, 星座グ ラフ法を試みてその有用性を確かめたものである。この 星座グラフ法は時系列的な SMR の值を角度が大きさに 比例する単位大きさのベクトルを求め, 最終位置を半円 内にプロットして星座状に表現するものである。例とし て, 対照的な地域差を示す全がんと脳血管疾患の SMR を用いて, 前者は第一次産業就業割合, 後者は人口密度 についての例を示している。この結果，全がんではほと んどどの県も円周上に位置し，この期間のSMRの変化 は見られないのに対し, 後者ではSMRの低い県と高い 県が円周上からの位直に差が認められた。すなわち、こ の方法は多変量グラフ解析法の一方法であるとともに 3 
期間以上の時間経過についてその観察が可能である点に 意義があることを立証したものである。

134 137（357〜360頁）座長 柳川 洋（自治医大） 134 : 高崎らは1969年〜 78年の10年間の主要死因 SMR およびその推移比の地理的重心を計算し, 肝硬変 は西日本に，また脳卒中は東日本に偏っていることを示 した。各県ごとの重心の移動と各種社会経済指標との関 係を主成分分析によって観察した。

135〜137：倉科，箕輪らは，「わが国における疾病楎 造の形成過程に関する研究」について 3 題の演題を発表 し, 人口動態死亡統計のコホート観察の問題点を肝硬変 死亡, 糖尿病死亡を例に考察した。

例えば1930年前後に生まれた男子の人口集団は心身形

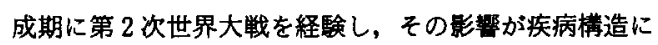
影響を与えていること、コホートによる観察では 1 年 1 歳単位の統計が得られれば, 情報量が多く, 精度の高い 翼祭が可能であること, 社会的, 経済的生活環境が地域 によって異なるので府県単位などの地域別の観察の有用 性などについての報告があった。

138～140（361～363頁）座展 森沢 康（独協医大） 138 : 中崎は, 人口動態統計, 患者調查を行い, 受療 率を独立変数, 死亡率を従属変数として回㷌分析を行 い, 受療率と死亡率がほほ線型に推移するのは結核, 悪 性新生物，糖尿病であり，とくに悪性新生物と糖尿病は 右上がりに平行して増加しているので, 今後, これらの 疾㭧の健康管理の一㕣の需要が望まれることを報告して いる。

139 ：西田は, わが国の感染性死亡の低下に化学療が 従来考えられていた程, 奇与していないことを明らかに している。座長は，それでは感染性死亡に寄与した要因 は他に何が考えられるかを質問したところ，栄䓹などが 考えられるとした。今後, 広い意味での生活水準の向上 等の内容分析も必要であろう。

140 ：福富は, PMR とその関連指標の整理と明確化 のために，年齢の PMR（全死亡に対する特定年齢階級 の死亡割合) と死因の PMR (全死亡に対する特定死因の 死亡割合）とに二分類し，後者の死因の PMRのうち， 死亡情報のみで算出できる標準化 PMR は，人口情報が ないと使えない相対 SMR の代用となるもので有用であ ることを強調している。

141～143 (364～366頁) 座長 方波見重兵街（公衆衛
生院)

141 ：府県別の死亡率較差の年次推移を死因別に㭘討 している。昭和 35 年〜 55年の 20 年間であるが，死因によ る変動は大きい。昭和 35 年と55年の相関係数で, 胃が h，脳血管疾患は高く，自動車事故は低い。即ち東京， 大阪，神奈川等の死亡率は低くなっているようである。 社会・経済的な変化との関連があるものと思われる。

142 : 沖縄県の死亡粠造の変化の中て, 筒炎・ネフロー ゼを取り上げている。男女共その死亡率がここ数年全国 より低下している。またコホート分析で，全国と比較 し，1881年～1890年生，1911年～1920年生，1921 1930 年生において異なっているように地域により，年齢によ って異なった傾向を示しており興味深い。

143 : 京都府での死因と健康指標との関連から, 保健 政策の指針を求めようとしている。脳卒中と子宮がんで は，人口密度，1人当り年間所得，老人人口割合との相 関保数の正負が逆である。永田（京都府医大）ょり，市 町村で指標の相関では，変動が大きく，人口での重み づけをする方がよいのではないか。そのプログラムがあ るので使用して下さいとの指摘があった。

\section{4～149（367～372頁） 座長 赤松 隆（琉球大）}

$144:$ 台湾の1982年における死亡解析で死因別分類か ら日本のそれらと比較を加え检討した結果である。乳児 を含む若年層ては台湾て高く，訂正死亡率より眺めた悪 性新生物のそれては台湾で低い值が示された。特に悪性 新生物の場合, 部位別でも日本のそれらとの差が認めら れ，肝癌が高率で胃癌が相対的に低率であるなど死亡順 位に差があることが示された。

145：カラチ地方の死因別死亡率を性，年齢別に区分 し推定を試みたもので，保健省の料が不十分なため， 臨床医療機関のそれを対象に検討を加えている。例えば 10〜45歳群で女性の死亡率が高い理由として回教の性差 別因襲の影帮などを挙げ，又，日本と比較した場合，推 定死亡率て 4 歳以下の感染性疾患では約 200 倍, 成人て も22倍, 栄䓹疾患 7 倍, 循環器系 2 倍などの值が示ざれ た。

$146 ：$ 誌上発表

147 ：日本における胃・十二指腸䜤よう死亡の1933年よ り1982年までの月別構造解析で, 月別死亡数の年次推移 を眺めると冬期, 夏期の間で周期的な振幅変動を示して おり, 最大月死亡数 /最小月死亡数の対数グラフ上での 推移では，男女共に年々隇少傾向が見出されるが，女性 の方が変動幅が大きい事が認められた。最大最小月死亡 
数比では，戦後の減少推移をたどっている部分が男女と もに大きい值を示した。

149 ：日本における自動車事故が原因となった疾病, 死亡の践造解析で，1950 1980年の間での年次別年齢階 級別死亡率は男女間で差が認められ，男子の方が，やゃ 平面的な死亡率の分布を示した。コホートで眺めた部分 ても女子群てはGombertz則に従っているが男子群で はその傾向が認められなかった。男女間の日常生活差の 影斐が同われる所見である。

\section{8～152（371～375頁）座長 重松詖夫（福岡大）} 148〜152の5 題の予定であったが，149は演者の都合 で綝りあがり前へ移行，4題の座長をつとめた。また 150 よび152は口演者が川口 宮前, 荒記 $\rightarrow$ 村田と変更 になった。

148：土建国保組合の資料による建設労働者の死因解 析の報告で,この種の小規模事業所労働者の調查研究は 貴重であり，今後もデータの稓み重ねが望まれる。主な 死因として事故，塺肺等の増加を認め，また職種別に渉 装従事者の悪性新生物, 石工の硅肺多発, さらに石工て は他職種に比べ平均余命がかなり短い等の所見が報告さ れた。

150 152：いずれも自殺死亡の解析報告, 150は 1955 79年の全国データによる一連の死因別死亡のコホ ート観察の1つで, 演者等のいうメッシュコホートM -1935は20才と40才で 2 度の自殺多発を示している点， また1955年を境にわが国の自殺死亡の好発地域が都市部 から農村部へ移り，発生秩序に大きな変化があったと考 えられるとの報告であった。

151および152は同じ研究者で，全国およびある大都市 の資料を用いた自殺の季節変動の観察である。全国では 春 $4 ， 5$ 月に高率, 冬 12,1 月に低率, 大都市では夏か ら秋が低率と差がみられ，自殺手段によって季節変動に 差があり，また大都市では手段別にも全国傾向とやや異 なる傾向を示すものもある。自殺の研究には困難が多 く，とくに手段別には成功率にかなり差があると思われ る点に関し䫟問があったが、これらは今後の検討にまた さるを得ない。

201 204（116～119賁）座長 加藤孝之（愛知医大） 201：22 49才の健康男子16人の24時間尿のCa, $\mathrm{Mg}, \mathrm{Zn}$ の排泄量の日内変動について検討した。田中 (大阪市大)加体重当りの補正と摄取量との関係につい ての質問があったが, 今回は予備調查で今後, 運動及び
食物や水の撖取等の諸因子との関係について検討したい と答えた。

202：24時間尿の食塩排泄量から食塩提取量を推定す る場合の問題を検討し，摄取量は同量であるのに排泄量 には個人差がみられ，その要因は追究中であると報告し た。鈴木（東大）は尿中食塩排泄鼍の第 3 日が少ない理 由を質問し，第 1 日と第 2 日は実験前の影警もあり個人 苃が大きいが第 3 日は実験食によると答えた。桜井（㦄 応大）は体重，体表面積，尿の流量と濃さ等についての 考虑の必要性を述べた。

203 ：低ナトリウム摂取者の多いニューギニアのギデ ラ族について，尿の $\mathrm{pH} と \mathrm{Na} / \mathrm{Cr}, \mathrm{K} / \mathrm{Cr}, \mathrm{Na} / \mathrm{K}$ ，血 圧值との関係について検討した。 $\mathrm{pH}$ の高いのは食事と の関係が考えられている。㖖藤（長崎大）功年齢, 結 婚，食事との関係についての質問と，カドミウム污染地 で血圧の低い者の多い問題について追加した。

204 ：高血圧の家族歴あり群となし群は血圧, 肥満度, 体脂肪\%及び血液，尿中の生化学的指標レベルに顕著な 差異を示さないが，血圧とこれらの指標との間の関連性 の強さが異なると報告した。山本 (大阪市大)，永井（自 治医大）から家族歴について，吉岡（慶応大）から血圧 の測定について，田中（大阪市大）加ら女性では脂質代 謝と閉経についての考虑の必要などの諸問題が質問及び 意見として出された。

205 208（120〜123頁）座長 佐々木直党（弘前大） 205 : 吉岡らの演題は SHRSP と訂正した方がよいと いうことであった。系川（京都大）はラットはアスコル ビン酸（以下アと略す）を合成するので，投与によって それがとまることが考えられ，発表の結果がアの作用て あるかどうか，血液・贜器中のア如何と質問したが，そ れは他の成績でたしかめられており，他の要因への影響 も考えられると述べた。森沢（独協医大）から血圧以外 脳への影響如何，笹川（近畿大）から SHRSPはどの亲 のものか, 座長から飲料水量との関係について質間があ つた。

206 : 小野らの報告は, マイコンによるラットの行動 調查という方法を用いたりチウム代謝・行動に対する食 塩投与の影揞をみたものであった。質疑・追加はなかっ た。

207：松田らの山形県庄内地方における住民の一日尿 中 $\mathrm{Na}, \mathrm{K}$ 排泄量を，アンケート調查，早朝尿を除いて 翌日の早期尿（とくに時刻を記録しない）までの蓄尿の 測定值についての報告であったが，野外における具体的 
な探尿方法に質問が集中した。斉藤（長崎大）一分を大 事にする，森沢（独協医大）男女の採尿の差がのべられ た。座長から一部 Kに差があるが食事内容との関連を 質問したがわからないとのことであった。

208: 演者は小泉から池田へ変更があった。食事の調 查地域のサンプリングと SMR の町村との関係をどう考 えるのか (度応大・桜井), 脳出血と脳梗塞との差 (杏林 大）について貿問があった。

209〜212（124〜127頁）座長 笹川喛成（近穖大） 担当演題はいずれも人体血清脂質に関する調㚗で,脂 質代謝をめぐる意見交換が行われた。

209: 早川（近畿大）らは一卵性双生児の血圧, 血清脂 質，尿中電解質，食品咴好などを調ぺて，血圧に及ぼす 生活環境の影響を述へたが，遗伝的背景を除去した考察 に興味がもたれ，同等血圧対の動向や生活咊境も話題と なった。

210 ：上田（鹿児島大）らは熊本平野の農家夫螮につい て血清脂筫を中心とした身体状況と食事や労鿰の状態を 四季に亘って調べ, それらの季節変動を述べたが, 生活 環境が酷似している夫㛿間で血清脂貿の動向が若干異な る点に興味がもたれた。

211 : 林 (大阪市大) らは新潟平野の莀民て 40 才以上の 循環器系発作がない3,406名について, 血圧, 血清 HDL-Chなどの臨床所見や喫煙など生活状況を調へて 解析したが, HDL-Chが血圧などの循環器病リスクフ アクターよりも肥満や飲酒に相関していることに興味が もたれた。

212 : 大本 (東邦大) らは魚好と肉好の健常者を対照に $し て$, 虚血性心疾患と脳血拴性疾患の入院患者について 血中脂肪酸や食生活などを調へ，患者群では食質の影幚 以上に飽和脂肪酸などが多いと述べたが，例数や採血に 関する討論も行われた。

213 216 (128 131頁) 座長 多田 学 (島根医大) 213：モデル動物SHRSPと対照としてWKYを用 い,リポおよびアポ蛋白を測定したものである。 SHRSP は 2 力月齢において血圧の上昇する時期であ り, 対照よりApo A-1の有意な隇少を示した。ApoE とApo-IV は既に 3 週龄において, SHRSPが対照より 有意に低下しており, 加齢による変化など観察する必要 がある。

214：地域における住民検診で選んだ耐栫能異常者 6 名と正常者44名について，糖が非醉素的に結合した蛋白
貿と赤血球膜および血獎中脂質成分との関係を調べた。 $\mathrm{HbA}_{1}$ は赤血球膜の脂質と, GPro, GAlb は血漿中の 脂筫と強い関連を示した。

215：動脈硬化の成因を検討するため，家鬼および七 ト血小板に対する miconazole mitrateの影腤をみた。 micronazole mitrate は in vivo て家鬼血小板機能を阻 害し, in vitro でコラーダン凝集阻, アラキドン酸凝集 阻害を認めた。

216 ：213と同じモデル動物を用い, 高脂肪・高コレス テロール食で飼育し, ApoA-1, Apo-E, Apo-IVの動 態を検討した。食事負荷により SHRSPはApoA-1， Apo-Eともに減少した。一方, HDL 分画で減少する反 面, リポ䖝白一Free 分画で増加していた。

217 219（132〜134頁）座長 竹本泰一郎（長崎大） 217 : 加齢ラットでは若齢ラットと比較すると血策総 脂質のアラキドン酸構成割合が增加する他は，肝脂質の 脂酸構成や動眽壁からのプロスタサイクリン放出量には 差異が認められなかったことが報告された。座長よりの 人に外種した場合の加龄の判断, 飼料組成の影響につい ての質問に対し、ラット15月齢が人の 40〜 50歳に当たる こと, 高脂肪飼料で加秢による変化が顕著となると回答 された。

218 ：垔硝酸ナトリウムを微量長期投与すると残存二 トロ基による心電図変化が認められると報告された。豊 島（愛知医大）ょり再分極相ての変化の有無について筫 問があり，共同発表者の木下（東京医大）よりマウスの 胸部誘導が難しいとの説明があった。また，座長より機 序及び量一反応系に関する質問があった。

219 ：脳卒中既往者（1 年以上経過）と健常者間の栄善 状態の比较が聞き取り及び陰膳方式での分析の 2 面より 行われている。吉岡（福山女子短大）より脳卒中の内訳 及び研究意図について, 田中（大阪市大）より所要量充 足率を用いることの適否について, 前田（要知医大）よ り身体活動（リハビリ等）の状況についてなど活発な貝 疑が交された。

220 223（135 138頁） 座長 清水忠彦（近幾大） 220,221 : 過疎地域における老人健康診査の循環器精 検の成績を解析した一連の報告である。220ては治療群， 非治療群の血圧, 心電図, 眼底検查の所見, 221ては眼 底細動脈硬化度と血清脂質值との関係をみている。老健 法によって全国で検㓌が行われている折でもあり，眼底 所見の健康管理における意義を検討する価值が大きい。 
討論として, 我が国における近年の眼底所見の変化をふ まえ，地域特性を背景にして，より一層の㭘討が行われ るよう要望があった。(訂正：演題220 本文上から 5 行 目 $1275 \rightarrow 1207$, 同 11 行目 $61.3 \rightarrow 64.7)$

222 : 住民 48 人について血清脂筫俌の測定及び栄養調 㚗を行ったものである。高脂血症についてはWHO 型 分䅡て比較している。蛋白, 脂肪, 糖の摄取量および充 足率, HDL, アポAI，アポA IIについて検討してい るが, 注目すべき所見として、アポA I, アポA IIが糖 の充足率と有意の負の相関を示した成績を報告してい る。（訂正：本文上から 5 行目 9 月 $\rightarrow 10$ 月, 同 6 行目 9 月 $\rightarrow 9$ 月または10月, 表 3 脚注 ** $p<0.001 \rightarrow 0.01$ )

223 : 女子中学三年生 157 人について血清脂質値を測 定, 家族歴, 食習慣, 発育歴との関係をみたものであ る。高コレステロール群は小学校 1 年からローレル指数 が高いが，身長の増加はかえって早い時期に鈍化してい たという興味のある現象がみられている。

\section{226（139 141頁） 座長 新井宏朋 (山形大)}

224，225：血中リポ蛋白に対する食事の影䇾について の実験疫学である。224ではアルコール捸取（ビール飲 用）の影響を検討したもので中性脂肪は上昇，コレステ ロールとアポ蛋白には影㬖なしとのことであった。ビー ル飲用による多量の水分摄取の影整はないかとの質問が あったが、影掣はないと思うとのことであった。225は 魚肉と獣肉の大量摄取の影䇾をしらべているが，食生活 パターンの相違（魚を多くとるか，肉を多くとるか）に より血中脂質の各分画の変動パターンにちがいがみられ るとのことであった。

226は汇紙法による $\mathrm{NaCl} / \mathrm{Cr}, \mathrm{K} / \mathrm{Cr}$ 比(24時間尿, 排 尿ごとに測定) の測定がフィールドで可能であり、これ が減塩指導の効果の判定に有用との報告であった。演者 は通常の保健指㱏に尿中食塩量の測定を追加すること自 体が減塩の実践に効果的であったと述へていた。疫学と 対策の両面からみて有意義な研究と評価できる。

227 229（142～144頁）座長 阪本州弘（兵庫医大） 227 ：体表面電位図から，心電図逆問題解を用いて心 外膜電位図を求め, 主として心筋梗塞の部位と程度を推 定する方法を発表した。この方法は標準12誘導心電図よ りも下壁梗塞部位の推定に有用であることを実例で示し た。この方法はQRS 波のみを用いて分析したもので， T 波は用いていないと述べた。

228 : 検診現場での血圧測定の客観性の上向と統計処
理の効率化のため血圧值認識処理システムを発表した。 1 波型中に 2 峰性が現れた所はコロトコフ音と関連があ り最大，最小血圧值を示すと述べた。 X一Yプロッター ての作図の意味，血管，压情報の生理学的意味の説明が 望まれる。

229 : 昭和 $53 ， 58$ 年の高血圧検診の結果をデータ・ベー スに記録し，各個人の 5 年間の血圧変動パターンを血液 所見により分析している。高血圧の改善に関与する要因 は血糖値，中性脂肪，肥満度であることを示した。デー タはすべて現地で入力すると述へた。

$230 \sim 233$ (376 379頁) 座長 青山英康（岡山大）

230 : 陳ら（東京大）か，64才の女性の症例について， 訓練前後に呼吸機能と動脈血ガス分析及び自覚症状調查 を行って，訓練効果の評価を試みたものであり，自覚症 状に認められた改善を科学的に表付け得る指標を追求し たいとの報告であった。

231：岡崎ら（度応大）がすでに「じん肺」について認 められた有用性を，肺癌㭧者に対して用いられた制癌剤 の作用による肺線維化の早期発見にも応用し得ないかを 確かめたものであり，公采衛生領域への本検查法の応用 について今後の検討が期待される。

232 : 浅野ら (名古屋大) か「胃切除」という生体侵熟 の発癌性について検討する目的で追跡調查を実施して， 調查結果を報告したものでありこの種成人病の管理と 追跡調査の方式について幅広い討議が行われ, 追跡調査 の效率化のためには, 本籍地の登録が必要であるとの追 加意見が出された。

233 ：勝田ら（名古屋大）か，北海道在住者について, その父祖の出身地による食習慣の健康への影響を検討し たものであり，死因への生活パターンの影響についての 今後の科学的検討の進展が期待された。

234～237（380～383頁）座長 山下節草（奈良医大） 234 ：地域住民の受療構造分析による, 地域の医療機 能充足状況の検討結果を報告した。南多摩地域の国保診

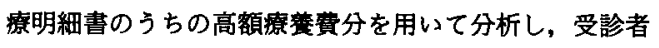
に高齢者が多いこと, 循環系の疾患, 精神障害, 新生物 が入院に多いこと, 新生物や神経系及び感覚器などの疾 患では地域外受診が多いことなどにもとづき, 急性短期 の疾患に対応する比較的高度な医療機能が不足している と結論した。

235 ：被差別部落住民の健康実態を明らかにするため の調查の結果の一端を報告し,「部落」の出生時体重は, 
対照地区に比べて小さく低体重児の割合が高く，その背 景として，社会経済的要因の長期的な影㖕があると考え られるとした。

236 : 私的医療機関 (内科消化器科)の診療記録にもと づいて, 日雇健保の被保険者の受療状況を検討し, 日雇 健保では初診の回数少なく, 初款 1 回当りの疾病数は多 いが, 疾病構造はほかの医療保険と変わらないと報告し た。年齢粠造, 職種のちがい, 肝炎等倡病種別による分 析を期待する発言があった。

237 ：無医地区住民を対象とする巡回診療の役割を評 価するために，検診成績を対照地区と比較㭘討し，巡回 診療は急性疾患に多く罹患する若年者に対しては受療機 会の保障の方法として有効てはないが, 慢性疾患に多く 罹患する老人に対しては役割を果たしていると報告し た。

\section{8〜240（384～386頁） 座曼 木村 受媛大）}

238 : 京都府の市町村別, 保健所管内別に, 老人医療 責が社会諸指標によって表される地域特性といかなる相 関をもつかを, 重回㷌モデル, 相関行列を用いて分析し た研究である。結果は, 農村・過疎的地域で低く, 都 市・商業的地域で高いという一般の予想を出るものでな かったが, 社会指標の検討, 医療費に大きく影響する健 康状熊, 受診動向, 受療内容等の指標を加えた分析が今 後の課題であう。

239 : 国民医療費の年齢陵級別推計值と, 患者調査に よる患者数との年次推移を用いて両者の関係を検討した 研究であるが，なお，現象の把暒にとどまっており，そ の解析は今後行われるものと期待したい。

240 : 広島県一町の国保レセプト記載のすへてての傷病 名を, ICD大分類にまとめた上，数量化理論第 3 類に よってパターン分類を試みたものである。医療費の構 造, 疾病構造を分析しようとして,レセプト偒病名を用 いる場合, 記載病名そのもの, さらにICD大分類を用

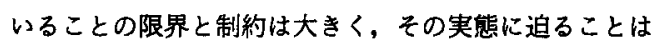
困難である。数量化理論等の統計手法を用いる以前の問 題として，研究目的に沿った資料，指標の吟味，検討が 必要ではなかろうか。

\section{1〜244（387〜390頁）座長 根岸笵婎（東京大）}

241 : 地域保健情報支援システムの開発研究というこ とであるが, システムのハード関係に関するもので, 特 に図形グラフィックに特徵があるようであった。アプリ ケーション・ウエアおよびソフト・ウエアの今後の開発
が期待されるところである。

242 : 不均衝な医師の市町村分布に関する考察である が，例としてあげた「高龄医師は医療の第 1 線にとどま るよりは保健活動の指等者として地方で活躍できるよう にする」という点をめぐって，吉岡（福山市立女短大）， 青山（岡山大）よりの貝疑が集中した。

243 : 医療サービスの地理的配置の研究 (第 1 報)であ るが，額田（東邦大）の昼間人口分布を中心とした考え 方は流石で, 今後の発展の期待できる研究発表であっ た。

244 : 府県別医師数の将来予測であるが, 出身地別就 業割合などの既存の資料より，昭和87年までの分布推定 をおこなったもので，医㙩資源の配分について貴重な示 唆を与えるものと考えられた。

245 247（391 393頁）座長 中村健一（高知医大) 245 : 畨科医師数の增加は歯学部所在地で著しいこと, 大都市周辺地域では人口増加に見合うだけの増加がみら れないこと，などを報告した。中屋（岩手医大）より大 学院設立以後地元に残る人が増えた，との追加報告があ り，座長は霜科医療需要の量及び質の変化も考虑に入れ るべきだ，と提言した。

246：住民のかかりつけ医に対する意識を調查し，健 康管理主体としてのとらえかたがそしいことを指摘し た。青山（岡山大）の「かかりつけ医の内容に問題があ り，その選定理由，年齢との関係などを検討すべき た。」との発言に対し, 演者は選定理由の第 1 位は「近 い」，高年者ほど「かかりつけ医あり」が増える，と回答 した。

247 ：住民と家庭医の結びつきの内容・程度を住民と医 師の両面から調查した興味ある報告で，医師側がより親 しいと考えている，とのことであった。吉永（広島大） より地域差や意識と受療行動との相違について, 青山 (岡山大)上り今後の家庭医のあり方について，それぞれ 有意義な提言があった。

\section{8〜250（394～396頁） 座長 渡辺 孟（愛媛大）} 248 : 人口対病床比がかが国最高の高知県の一般の入 院件数分布をみると，私的病院が $64 \%$ ，診療所が $16 \%$ と いずれも高く，入院日数も長く，循環系・筋骨格系が多 い特性を示す。高知市に広い診療圈をもつ病院が多く， 幡多地区もそれに近い。地域医療計画を策定する際,こ のような医癔需給上の特性は重大な要因となるであろ う。 
249 ：東京の歴史ある某老人病院の入院患者ては ADL の低下，異常精神症状の有無と介境者との関連が注目さ れ, 病院での期限切れや経済的理由で転院してきてい る。介讙負担の過剩が治療を目的とする例より多く，自 宅で引き取れず退院できいのも介護の過剩負担が主な 理由であるなど，老人問題の一つの焦点が浮彫りにされ た。

250 : 健康保険組合の財政収支は被保険者数と平均年 齢に大きく影鼍され，200人以上では 7 事業所すべてが 黒字となっているように，人数の多いところではたとえ 赤字でもその值は小さい。平均年龄では黒字事業所で 8 歳ほど低く，人数よりも平均年龄の方が影幚が大きいな ど保険組合を構成する上てのポイントを明らかにした。

\section{304（145 148頁）座長 高田 勗（北里大）}

301，302：各種 Life style・保健習摜が健康に及はす 長期的影管を定量的に把握する目的で，姉姝染色体分体 交換（SCE）頻度を指標として，末梢りンパ球染色体 DNA 変異の㭘討を行った研究である。保健習慣とし て, L. Breslow の 7 つの健康的生活習慣を日本にあう よう改善して mental stress を含む 8 項目の生活習慣を 取り上げ，SCE頻度上昇について，喫煙および飲酒習 鏆の間に亟めて強い関連性のあることを明らかにした興 味ある研究である。西住 (佐賀医大)，遠藤(山形大)，青 山（岡山大），白石（公采衙生院）の諸氏より活発な質疑 が行われた。本研究の今後の継続とその発展が期待され るところである。

303：一般成人に行われるAMHTS 受診者の日常生 活を調查し，肥満との関連について統計学的に検討した 研究である。近藤（慶応大）上りの追加討論があり，健 康診断結果の異常所見者との関連について, 今後解析さ れることが望まれる。

$304 ：$ 中高年者の保健行動と健康状態との関連につい て，リジット解析を用いて，一般住民と医師を対象とし た調査結果を検討した研究である。約 7 時間睡眠，活発 な運動，非喫煙，若干の飲酒機会，肥满度 $\pm 10 \%$ の人の 健康状態が良好であることを示したが，矢野（帝京大） より生活習慣の相互の関連性について質疑があった。今 後の研究発展のため, 時系列な継続研究を行うことが期 待されるところである。

305 308（149～152頁）座長 近藤東郎（慶応大） 305 : 本発表は, 高知県幡西地域における健診受診率 の低下を機に，受診促進又は抑制要因を探求したものて
ある。その結果，中年以降における加龄，自由な受診時 間の留保などが促進要因であことを明らかにした。こ れに対して，その他の要因を如何に考えるかの討議があ った。

306：本発表は，沖縄県南部地域において65才以上の 60例のアミノ酸分画を測定したものである。その結果， 総たんぱくは加龄で低下傾向にあるが，アミノ酸プール は増大する。しかし，リジン,アラニンなど一部のアミ ノ酸は65〜69才で，それ以上の年齢層より低值を示すこ とが明らかであった。

307 : 本発表は, 老齢者の脂質代愔変化を TC, HDL CLに加えて，アポたんぱくの変動から追求したものて ある。その結果，アポたんぱくは施設内老人は一般健常 老人より高く，ねたきり老人ではアポ $\mathrm{E}$ 量が高かった。 これに対して，対象の生活行動に関する質疑が行われた。

308 : 本発表は, 肝胆道系疾患の集団検診における超 音波䛦断の有用性を，問䛦，血液化学検查と関連つけて 検討したものである。その結果， sensitivityをあげる には各組合わせは有効であるが， speciticityはさがる ことが明らかにされると共に，超音波診断を行うに当た っては, 標的臟器を確認する必要性が認められた。

309 312（153～156頁） 座長 的場恒孝（久留米大） 309 ：看讙学生 100 名を対象に健康調查 (THI) を 3 年 間行い，身体的項目の変動が大きく，精神的変動は少な いことを示す。しかし経年的変化も追求してほしい。設 問130と多いのであきることはないか(産業医大・大久保) との質問に，1年のみであること、マークシート式であ ることなどからそのようなことはないと答える。

310 : 精神的不安度をSTAI を用いて測定して信頼 性, 妥当性ともよいことを示す。騒音懪露後の A-state 湘定で，fr はどうか，A-traitはどうか（岡山大・金沢， 度応大・桜井）との質問に，今後行ってみる。騷音 $90 \mathrm{~dB}$ の A-scale が小さいことは生理学的, 心理学的に意味が ありそうで, 統計的有意差におわらず追求してほしい。

311 ：検钐データを大型電算機に fileすることで, 個 人の健康状態が経年的に把㩧できることを示す。検查值 の処理で SD より CV で行ってみたら（山口大・大崎）と の提案などある。

312 ：健康管理活動における電算機利用の利点をのべ る。具体的な質問（新日鉄・酒井，産業医大・大久保) に成人病㭘診は 2 力月間 1 日100名を目安に行う。有害 業務者はいない。入力は検診直後に行う。プライバシー 問題は現在までにない。厳重に管理している。今後電算 
機がフルに活用される分野である。

313～316（157～160頁）座長 望月藏夫（川崎医大） 313 : 労缏, 生活環境の変貌と高齡化の状況化で健康 管理の重要性が高まっているが，日常生活の中での健 康・体力づくりは必ずしも実効を挙げていない。有効な 対策をたてるための基礎資料を得るために大都市, 中都 市, 農山村の3 地区を選び，40才以上70才未満の住民に ついて健康, 生活に関する質問表調查を行い, 演題 313〜316において一連の調查成績が発表された。本報て はそのうち体力づくり, 健康づくりの取組の奏態につい て発表された。

314 : 前報に引きつづき, 成人の健康管理の実態につ いての質問表, 調查の結果をまとめたもので, 地域別, 職業階層別に軽い病気の際の医療行動, 胃がん検診の受 診状況と末受診の理由, 日常生活時の健康相談等の相 手，その他の検診受診状況について報告された。

本演題について，よりきめの細かい健康づくり対策の ためには地域別のみでなく職業階層別の実態把握の必要 性が追加された。

315：前報に引きつづいて, 日常の健康づくりの中で 食生活の面での “気くばり”についての実態調查をまと めたもので, 大都市, 中都市, 農山村住民について男女 別に朝食の規則性, 家族との食事状況, 間食または夜食 の状況，食事面での“気くばり”の状況について発表さ れた。これについて成人期以前の健康教育の時期につい て討論された。

316 ：前 3 報に引きつづいて, 健康, 体力づくりを進 める上で, 健康 ・医療情報の効果的な提供と有効な活用 方法が必要であるが，前述 3 地域住民についての実態調 查が報告された。地域, 性, 年齢別にみた日常の健康医 療情報の入手程路, 入手経路別の有効性, 情報入手経路 別胃がん検診の受診状況, 老人保健法の周知状況, 情報 の入手程路と健康，体力づくりに対する“気くばり”の 状況について報告され，今後の健康づくり活動への問題 点を提起して興味があった。これに対して健康医療情報 の入手後の住民の態度, 行動の変容についての調査項目 追加の必要性, かかりつけの医師, 保健壃あるいはマス コミ情報の健康づくりへの関与について, あるいはキャ プテンシステムの兴入などニューメティアの普及, ヘル スクラブ, 健康コンサルティング事業などの普及と健康 つくりの問題などが論議された。

317～320（161～164頁）座長 大井 玄（帝京大）
317 ：老人ホーム老人30名について健康習慣，自賞症 状，主観的健康観，主観的洞足度と ADL，友人の有無， 電話をする回数などの因子との相関を観た。老人は健康 習慣に留意する率が高く，自賞症状は外出回数が多いと 良くなっていた。満足度は家族の面会の有無によく相関 しているので家族のサポートが重要と思われた。

318 : 悬知県の町在住65才以上の958人の男女につき日 常活動性と生命予後との関係を観た。ADL が高く、ト ライブゃ旅行をするような活動性が高い者の予後はそう でない者よりも良かった。

$319 ， 320$ : 老人の疾呆の予後は㻴境条件により影響さ れ,さらに家庭介讙には数々の困難が認められている。 その問題解決のためには社会的, 政治的協力が必要であ る。

321 324（165～168頁） 座長 近藤壱代太郎 (北海道 太)

321 : 沖綿読谷村の70才以上の高齢者の $20 \%$ は知的低 下を示すが，社会的適応が良いので，本報では東京都と 比へてその要因を分析した。ADLを一致させ，独居者 を除いて比へると，知的低下があっても読谷村では趣 味，家事上の役割が保たれていた。

322 : 高齢者のボケの客観的評価のため, 尿中カテコ ールアミン $(\mathrm{CA})$ を調へた。椥呆老人の值は同龄者より 低いが, 面会, 入浴, 治療処理などに反応して増した。

323 : 和歌山県山間部て 65 才以上の全老人 $337 て$, 長谷 川式スケール (HS)，ADLなどを調へた。加齢ととも にHSが減したが，女で著しかった。世帯構造による 差はなかった。

324 : 鳥取県の10市町村の循環器検診 (昭和57年) の方 法は多様であったが，その理由は受診率を上げ，地域の 要望にこたえたためだった。しかし老人保健法施行で, 単一となり，地域比較も容易になる。

325 327 (169 171頁) 座長 武田真太郎 (和歌山医 大)

325 : 名越らは，老人健康診査の受診率の低かった広 島市において，受診者と末受診者との比較検討を行った 結果として，心理的要因には差を認めなかったが，末受 診者には受療中のものが多いこと，また，健診の季節， 曜日，時間に考虑すべき点が多いことが報告されたが； 集団健診の受診率が低いことは都市部に共通した問題点 であり，その背景を明らかにして対応を考える必要があ る。これに対して，大井 (帝京大)，渡辺 (愛媛大) から， 
住民の希望が多様であり対応がむつかしいこと，ADL の低下なども関係するのではないかなどの意見が出され た。

$326 ：$ 徳留らは東京都監察医務院が昭和58年に取り扱 った東京都内独居者死亡例 1 ,084例の実態を分析し，死 後 1 日以上释過して発見された高踰独居者死亡例が増加 しており, 今後さらに人口の高龄化が進む背景を考える と, 保健所，福祉事務所等の行政と地域住民が一体とな っての独居老人対策が必要であることを指摘した報告て あった。これに対して，渡辺（愛泼大），山本（広島大）， 田中, 安西（昭和大）らから, 死亡例の職業, 性別, 死 因分類の取り扱い等についての㗨問があった。

327 : 堀川らは，地域における老人の保健福祉需要を 分析するために，65歳以上のアンケート回答者 1,534 名 のアンケート調査後 2 年 6 か月の追跡期間中の死亡例に ついて標準化死亡比を求め, アンケート調查時の健康状 態，生活習慣と死亡率との関連を検討したもので, 健康 状態，日常生活動作，仕事または家庭内の役割，友人， 入院歴，便通，健診受診の有無に有意の関連を認めたと いう。これに対して渡辺（爱媛大）から，外出行動の行 動笻曲は老人の $\mathrm{ADL}$ をよく反映するという意見と，そ れに伴う交通事故死の有無についての質問があった。贵 重な追跡資料であるのでさらに追跡調查を続け，詳しく 分析されることを期待したい。

328～330（172～174頁）座長 藤波算二（東京医大） 328 : 在宅枕たきり老人に必要な社会的援助の優先順 序を，介蒷負担度の面から明らかにせんと試みたもの て，全体としては老人の重症度の影愺が最も大きく，介 荄者本人は老人の知力低下度の大きい程, 又自身が職業 を有する場合程負担が大きいと感じ，調查者である保健 婦は老人の ADL の低下度と介荄者の子供の有無の影䇺 が大きいと推定していることを報告した。図の文字が小 さく見にくかったのは残念である。

329：独居老人の食物掞取の状況を中心に謂查した結 果，栄着所要量を满たす者が少ないことを春例を挙げつ つ報告した。この調查結果もさることながら，演者がむ すびに記したごとく，この研究自体が老人対策の為の地 域保健活動推進に果たした功紿は大きく評価されるべき であろう。

330 ：老人保健法の保健事業の対象者を把挃すること は事業計画策定の上で必須の事でありながら，実際には その概数を得ることさえ困難で，法の実施に難涉してい る市町村が少なくないと聞いている。本報告はその要望
に答えるべく実際の調查結果から，健診対象者把暒の為 の推定式を案出したものであり，時宜に適した研究であ る。今後更に演者をはじめ多くの研究者による追試，検 討が望まれる。

331 334（397〜 400頁）座長 米川嘉則（京都大） 331 :座長の川崎病発生の疫学特性と原因に関する 種々な説に対する関連性についての質問に対し，演者は 疫学的特徵からは感染症が疑われること, 又疫学データ からはダ二原因説の説明はできないと答えた。

332 : 例数が少ないので外国の論文など参考になるデ 一タはないかとの座長の質問に対し，演者は一報だけ外 国の論文があるが，その報告も例数が少ないと答えた。 又今後例数を増加して統計的な検討を加えたいとのへ た。

333：木村 (京都大) よりセレンの定量は水素化物原子 化法が放射化分析法より感度が良いと云う指摘に対し て，演者は今後検討する予定であると答えた。

334 ：座長の遭伝性ポルフィリア症の症状は腹痛たけ か，又そのような人に対する特別な注意があるかとの質 問に対し，演者はこの例では腹痛のみであるが，外国の 文献では腹痛発作の他に吐気，便秘，下痢，けいれんな どの記載がある，又腹痛発作の発生する前に患者の眼の 色が変化するが，その時点で点滴を受けると腹痛発作が 軽症で終わると述べた。

335～339 (401〜 405頁) 座長 節 光長（聖マリアン 十医大)

335 ：大阪府におけるビュルガー病患者について，年 齢別考察と性比について述へ，男の槵者数は女子の約 15 倍と従来の報告より高い数值を示した。また，重視され ている喫煙との関係については, HDLコレステロール の重回帰分析成績より，喫煙がこの低值の関連要因と考 察している。血清総蛋白, 総コレステロールが，いずれ の年齢階層でも，全国平均より低く，食生活と疾病との 関連の可能性を示唆している。鑑別を要する類似疾患に ついては，述べられなかった。

336 :レックリングハウゼン病の頻度を, 患者調查お よび死亡統計から，仮定をおいてそれぞれ推定したもの てある。重症例，軽症例に加えて，受診してない患者数 などについて考察を加えている。また文献的に，有病率 および精神掘滞者施設にいる患者数よりの推定值を，日 本人，人口にあてはめて，検討を加えたものである。 $337 ： \mathrm{DIC}$ 診断に有用とされている諸検查項目につい 
て，それそれれ検查項目間の相関係数と主成分分析を行っ たものである。

性別, 年令, 既往歴および表 2 の経時的データーの数 值について質疑，討論が行われた。

338 ：パーキンソン病と流行性耳下腺炎の既往との関 連を追求するために, 対照を設定し, 血清ウイルス抗体 の測定を行ったものである。パーキンソン病患者の抗体 価が高いという結果を得られなかったと報告し，この原 因についても考察を加えた。

$339: 1972$ 年と1981年の全国調查, 人口動態統計を用 いた近年の再生不良性實血の疫学像の変化を，検討した ものである。

結果は，1)再生不良性盆血者者の平均死亡年齢の上 昇, 男女差が認められないこと, 有病者の平均年齢も同 様高齢化が観察されたこと 2) 長期生存者の增加 3)有 病者における軽症，中等症の增加を，結論づけている。

\section{343（406 409頁） 座最 前田和甫（東京大）}

340 ：鳥取県下における難病患者の実態調查である。 昭和55年 1 ヶ年の患者で，総数185名についてであるの であまり一般的なことは結論しにくいが，国の難病対 策も開始後15年近くになるので，地域におけるきめの細 かい対応が叫ばれている事態に沿うものである。地域的 な限定があっても腎不全という疾患が，患者の生活を甚 だしく障害していることが浮彫りにされた。

341 : 宮城県下の難病患者のうちの, SLE, ビュルガ 一病，再生不良性貧血の 3 疾患の新規発生率の推定をし たものである。手法は県下最大の $\mathrm{T}$ 病院の受骖者の割 合が, 年次, 疾病によっても大きく変わらない点を根拠 としている。取り上げた 3 疾患いずれについても，推定 された結果は全国的な当該疾患の傾向と変わるものでは なく，演者らの仮定が妥当なものであったと思われる。

342 ：厚生省患者調査の資料の 6 ヶ年分, 昭和 $51 \sim 55$ 年のものを资料として，27の難病患者の受療実態を調ぺ たものである。難病の一般的性状からして当然のことで あるが，病院受診で入院を経験しているものが多い。

資料はある特定の 1 日についてであるが， 6 ケ年，長 期間のものをまとめると，患者の実態を知り得る資料と なる点を示唆する有意義な仕事である。

343：前題と同じ研究室からの発表で，同し 1 日分の 資料を基にしての難病患者の有病率の推定をしたものて ある。最近，難病患者の高齢化が云われていることを証 明している。前題と併せ，共に結果が他の方法で示され ている事柄とよく一致することから，1日分の資料の活
用性についての高い可能性を示すものであろう。

344～347（410～413頁） 座長 酒井恒美（山口大） 344 ：耐糖能低下者について，その栄養摄取状況，臨 床検查值などを取り上げ，多変量解析による検討を行っ て明らかにした特性が報告された。渡辺（三井銀行健康 開発センター) から, 糖質摄取量の低い群と高い群の割 合、食事コントロールに当たって糖質，脂質の妥当な摄 取量などについて質問がなされた。

345 ：寒冷 $\left(4^{\circ} \mathrm{C}\right)$ 暴露によって, ラットの糖質代謝， 脂質代謝に変化がみられ，さらにSTZ 投与後の代謝動 態にも変調の認められることを明らかにした実験成綪が 報告された。酒井（山口大）が，寒冷暴露中止後におけ る獾得された特性の回復について質問した。

346 ：II 型糖尿病と彰断された職員の健診成績を検討 し，コントロール不良群では血清脂質值など動脈硬化関 連因子に好ましくない状態が認められたが，コントロー ル良好群では非楉尿病者群と差がみられなかったことが 報告された。事務系従業貝での糖尿病り患率について中 野（近幾安全衛生サービスセンター）より，食事指荨の やり方について酒井（山口大）ょり質問があった。

$347 ：$ 昭和52年日本病理剖検輯報に記載された症例に ついて，糖尿病にかかわる病理診断と臨床診断との対応 を検討した成續が報告された。酒井（山口大）が，診断 技術の向上によって正診率は上がるだろうかと質問。

348～352（414～418頁）座長 㣙木 劣（日本医大） 348 ：無症状胆石保有者の症例群と対照群とについて 血清脂筫を中心として比較検討し，症例と対照との間に 差が認められたが，症例群のうちでも男と女とではかな り差がみられた。更に胆石症と無症状胆石症とでは，そ の発生機序が異なっていることが考えられると言及して いる。

349〜351は慢性肝疾患の鑑別評価についての興味ある 演題である。

349：表 1〜表 4 に記載の各疾患群の真陽性率を判別 分析法による判別率と訂正。本研究では 3 群間の判別分 析において，選別された 9 種の有効変数を用いることに より CPH はほとんど正確に診断され，CAH，LCにつ いても各 2 群間の判別分析により相当程度の真晹性率を 認めている。

350 ：あらかじめ腹腔鏡肝生検により分類された CPH, CAN, LC 計107症例について, 日常の血液生化 学的検査に加えて, 肝外で合成される蛋白である $\mathrm{ACE}$ 
を加え，その評価を行っているが，血清 ACE 活性の湘 定は慢性肝疾患群の鑑別に際して, 判別奻率の向上に役 立つと考えられる。

351 ：慢性肝疾患における血液化学的検查の主成分分 析により 3 疾患に共通した 3 主成分を抽出した。第 1 グ ループは $\mathrm{rG}, \mathrm{ZTT}, \mathrm{A} / \mathrm{rG}$ て肝細胞外の免疫反応を反 映している因子，第 2 グループはGOT, GPT，O/Pて 肝細胞障害の程度を反映している因子, 第 3 グループは $\mathrm{TP}, \mathrm{A}, \mathrm{ChE}$ よりなり肝内代謝障害の程度を反映して いる因子と考えられる。

352 ：図 1，表 1，表 2 はいずれも男のみの数值であ る。剖検例恃非剖検例に比べ肝癌を合併する例が多い。 次に, 臨床猃断と剖検ての主病変を比べ，誤診率を $4 \%$ と見棈っている。また，原発性肝瘦における肝硬変合併 割合は病理剖検所見に比して死亡小票での記載は少ない ことを指摘している。

401 404（175～178頁）座長 三好 保（徳島大） 401：農作業従事婦人の定期健康診断に際し，鉄欠乏 と赤血球避離プロトポルフィリン及びへムや Hbの蓄积 挙動を検討したものである。Hb 低值群だけでみると相 関が高くなるが，血清フェリチンの增加に伴う FEP/ HEMEの低下は少ない。生体内貯蔵鉄は個体別に総量 としてとらえた上で，血清フェリチン等を指標とする検 討が今後望まれる。

$402 ： 21$ 組の夫婦を対象とし，1970～71年と1982年に 年 4 回, 連続 3 日間の食物秤量調查をした成績の 10 年間 の比較である。摄取量は項目数，增加率で妻の增加が多 くみられ，夫には增加は少ない。妻は $\mathrm{Hb}$ 值の有意な改 善增加がみられ， $\mathrm{Hb}$ 値のやや向上又は変化なしの群に 摂取量のレベルが高く，全体に動物性食品鉄の摄取增加 が Hb 值向上に役立っていた。体重の増加などの加缷に 伴う健康管理上の問題も派生してくるので考虑する必要 が認められている。

403：八淟山地域の昭和51年から20回にわたる2,629名 の栄養調㚗成績である。脳卒中死亡率の高率地域で，食 塩摄取量が高く，動物性食品の摄取量が少ない。自家生 産食品への依存性が高いが，調理する主㛿の意識改革は なかなか困難であり，改善され難いと述べられた。

404 : 平地農村地区と市内農村地区の栄養摄取と検診 結果の比較研究である。両地区の栄養調查成縝と血夜・ 生化学の值は必ずしも平行していないので，今後は個人 のデータの分析を個々に併用して検討したいと述へられ た。両地区の VC 摄取量の低い点について会場からも質
問がよせられた。

405 408（179 182頁） 座長 内田昭夫（千葉大）

405：血清 GOT・GPT 活性值とビタミンC との関連 を，青年 (大学生)と老年について調查したものである。 青年ては，GOT值は摄取ビタミン C と GP 值は摄取・ 血清ビタミンC との間に負の有意の相関がみられたが, 老年層ではみられなかったとの報告であり，GOT， GPT とビタミンC との関連についての質問があった。

406 : 前演題と同様の一連の報告で, 血清 LDH アイ ソザイムと血清ビタミンCとの相関をみたものである。 血清 $\mathrm{LDH}$ 活性値と C との間には有意の相関はみられな かったが, LDH 分画比との間では, 4 分画, 5 分画で 有意の負の相関が認められた。 $1 ， 2 ， 3$ 分画では認め られず，4，5分画で認められたことについて質疑があ つた。

407：アルコール性脂肪肝発生についての糖質摂取の 影響を、ラットを用いて調べた。糖質が少ないと，アル コール脂肪肝の発生が影著であることを生化学的, 病理 的に明らかにされた。飲酒時の糖質摄取の重要性を示唆 した興味ある報告である。

408 ：高龄者の食生態について，独居，同居，老人夫 妻に分けて検討された。独居老人に，食品摂取において 多くの問題があることを指摘した報告である。それにつ いて，高齢者であること以上に，家族形態そのものの影 繁がより大きいのではないか，また生活歴との関連をみ る必要がある等の意見が出された。

409 412（183〜186頁）座長 中野英一（杏林大） 409：魚介類が海水由来の菌によって污染されるのは 主として市場における周辺海水を用いる水洗による二次 污染とし，市場内における水揚げ魚介類の水洗用海水か ら除菌することが企図されその除菌装置（系統）が一案 として提示された。食中毒発生数の隇少のために行政的 な措置による市場使用水の質的規制が行われるべきであ るという結論であった。

410 : 腸炎ビブリオのすべてが必ずしも易真水性とは 限らず，耐真水性のものもある点から，易真水性株と耐 真水性株の生物学的性状を比較梌討したが両者の間には 本貿的な生物学的性状の差は認められなかった。実験方 法について検討を加えさらに追求する必要があろう。

411 : 食肉用豚の中の発育遅延豚の原因を追求した研 究報告である。血清中の蛋白分画值には対象となった発 育遅延豚と対照群の健康豚の間に大きな差はなかった 
が, 䁍器からの菌検出率は健康豚に比し発育掘延豚の方 に高かった。このことから食肉用発育遅延豚については 屠場における細菌検查の必要性が強調された。

$412 ：$ B. cereus の食中毒起因菌としての分布状態を屋 内環境と屋外環境に分けてみたところ，屋内環境におい ては血清型からみて多くの種類がみられたが, 展外環境 においては少数の型に限定されていた。また，嵒吐型と されるものの中にも下痢原性を示すものがあるので菌分 離の際の型別だけで考えるのは不十分であることが指摘 された。

413 417（187〜191頁）座長 竹村 望（慈恵医大） 演題 413 と 414 は摄取食物と疾病発生との関連性を疫学 的方法（共に聞きとり調查）により解明を試みたものて ある。

413 : 沖縄県で多く飲用される民間の飲用植物と疾病 との関連性を榆討し, 飲用植物と各種疾患の関連を odds 比で検討した結果を示した。

414 ：秏癌に対するハイリスク要因として高蛋白食, 高脂賈をあげて摄取量の計量化を試みている。この種の 調查研究方法の今後の発展が期待される。

$415: \mathrm{NaNO}_{2}$ の妊娠マウスへの投与による胎仔への 影響，さらに次世代への影艘を検討し，この中間報告て は著明な影整は見られていないようである。質問討議と して, $\mathrm{NaNO}_{2}$ の $120 \mathrm{mg} / \mathrm{kg}$ の投与量の適否について, また $\mathrm{NaNO}_{2}$ 投与によるメトへモグロビンの形成によっ て胎仔への酸素不足が影䉕することはないか，また飼料 中に魚粉などあるため 2 級アミンと $\mathrm{NaNO}_{2}$ との反応に よるニトロソアミンの生成とその影警がないかという意 見が述へられた。胎仔の骨格変化も検討するようにとい う発言があった。

416: リノール酸過酸化物の変異原性を $\mathrm{S} 9 \mathrm{mix}$ 存在 下で TA98 および新しい菌株の TA102 で認め, 精製過 酸化脂質では量一反応関係が示された。討議として, 生 成する活性酸素による殺菌作用, TA102のコントロー ル値の高い欠点など, いくつかの問題点が示された。

417 ：柑霣に用いられる食品添加物のモルホリンと 悪硝酸との反応によるラット胃内におけるニトロソモル ホリンの生成とその影䇾について，そしてビタミンC, グリチルリチン, 人参エキス, D-グルカンなどのニト ロソ化の抑制作用とその影䇾について検討した結果が報 告された。ニトロソ化合物による発痽の研究は多いが, ニトロソ化合物の毒性についての研究は比较的少ない。 本研究では生成されたニトロソモルホリンの肝毒性と,
ビタミンCなどによるニトロソ化の抑制に伴う毒性の低 下など興味深い結果が報告された。

418 421（192 195頁） 座長 角田文男（岩手医大） 418 : パプアニューギニア低地に居住するギデラ筷の 毛髪について，プラスム発光分析によって微量元素11種 の含有濃度を測定し，性・年齢・村落間の差を検討し，か つ試料洗浄による含有量の変化を報告した。

含有量そのものについて，石沢（広島市衛研）より鉄 の值が従来の報告に比し異常に高いと指摘されたが, 目 下この種のデータの集程段階で, 付着土壤のためか, 飲 食物による影響なのか，今後に検討のまたれるところ で，生態学的考察を加えるまではは至らなかった。

419 : 去年の本学会に引続いての報告で, 牛の初乳に ついて低分子クロム結合体を分離し，それらのGTF活 性を検討した。その結果，分離できた 4 種の低分子ク口 厶結合体のうち，酸性物質のひとつに G T F 活性を認 め,これが生体内におけるクロムの移動形態と必須金属 の役割とを示唆しうる興味深い知見を示した。石沢（広 島市衛研）より乳の種属差，殊に人乳についても同様か との質問に対して肯定的見地から実験を進めているとの 回答がなされた。

420 ：人のフッ素摂取源として主要な食品のひとつ, 米のフッ素含有灌度について分析法の検討および中国と 本邦各地の産米の測定結果を報告した。分析法として灰 化一微量拡散法を適当とし, 中国産米が本邦産米より高 值を示し，かつ本邦産米のフッ菜㴤度に地域差を認め た。原 (神奈川菌大), 古山 (昭和大), 河野 (福井医大) と分析精度に関する筫疑応答がなされたが，筆者の20数 年間の検討経験からして，まだ確かに推奖しうる方法を 見いだしていない。目下のところ，同一人が同一方法て 同時に測定したデータならば，環境要因などの影響を解 析することは許されると考えている。

412 ：人のフッ素クリアランスと腎機能との関連を詳 細に検討した報告である。先ず，千余名の健常者につい てフッ素クリアランスを検討した結果, 高齢者群（60才 以上）では，それ以下の年龄群より約 $15 \%$ 低下すること を認め，次いで慢性堅不全の者ではフッ素の排泄障害が 認められ，フッ素の体内蓄積を示唆する見事な知見を示 した。原（神奈川歯大）から血清フッ素の分析精度, 堀 内（日大松戸歯学）からクリアランス湘定法について質 疑応答がなされた。

422 426（196～200頁）座長 佐蕋重夫（山梨医大） 
422 : 低出力原子哣を用いて茶莱中 Mn の放射化分析 を試みた報告である。Mn 含有量が高い茶葉では試料に 前処理を施すことなく湘定が可能で，原子吸光法による 测定結果とよく一致していた。ただし，本研究で用いた 原子炉の出力が小さいため, 生体試料を前処理なしに測 定に供することは無理ということであった。

423：プロイラーのコクシジウム予防のため飼料に添 加されるナイカルバジン (NCZ) の市販哭肉中の残留状 況を調查したものである。検查試料131例中 $13 \% に \mathrm{NCZ}$

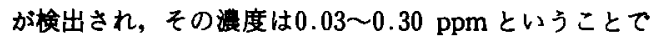
あった。この程度の残留が直ちに人間に影響をもたらす ものではなかろうが,ささらに㭘查対象を広げて残留状況 を調㚗されることが期待される。

424 ：リボフラビンの久そが食道癌の発生に関係があ るとする疫学的連性を背景に, 赤血球の FAD 要求性と 食生活との関係を追求した。FAD 要求性と捸取栄盖と の間には有意の関係はなかったが，自炊および自炊・外 食の男子学生に高いFAD 要求性を示すものが多いとい うことであった。青年期の食生活が将来の病発生にどの ように関連するか follow up を注目したい。

425 ：高校生・中学生における DF (食物䄉維) 摄取量 は $1.8 \mathrm{~g} / 1000 \mathrm{Kcal}$ 程度に過ぎない。そこで麦飯を中心 とする献立 (DF： $7 \mathrm{~g} / 1000 \mathrm{kcal})$ をつくって試食させた ところ, 対象者の 6 割が “いつも食へたい”と答えたと いう。しかし長期間にわたってこの献立が受け入れられ るかどうか疑問であり，さらに変化に富んだ献立づくり を検討したいということてあった。

426 : 健康管理対象世帯 (高血圧, 栯尿病, 高コレステ ロール血症）の食品捸取状況および生活形態に関する調 査報告である。糖尿病による健康管理対象者を抱える世 带の約半数が食事療法の重要性を認識していないという ことである。健康管理対象者だけでなく, 調理担当者を 含め家族全員に食生活の重要性を認識させる必要を改め て感じる。

427 430（201 204頁）座長 田中恒男（東京大） 427 : 本報告は, ジコピリン酸が細菌胞子の主要成分 であり，胞子にのみ存在する特有な成分であることか ら,この有機物に対する電子レンジの影望について夷験 を行ったものである。その結果，単なる加熱法より早く 遊出してくる事実が明らかにされた。しかし，この調理 法は一般の加熱調理法と比べ, 微生物に対する効果 (ジ コピリン酸遊出量)に差はないと報告された。

428 : 本報告は，かねてから健康によいとして評価さ
れていたゲルマニウムの，食品における含有量と摂取量 について，兵庫県下の食品摄取量データを資料とし，食 品を42種集め, ゲルマニウム含有量を湘定，そのうち 6 食品を指標として摄取责の推定を，市町村単位で分析し たものである。ただ本報告で欠けている点は，食品生産 地の土壤中のゲルマニウム含有量の測定, 生体内の chemochineticsの追究であり, 今後の分析にこれらを 加える事が指摘された。

429，430：本報告は，我が国の中央紙一紙を選び, 1982年, 83年の 2 年間について「食」に関しての一切の 記事を収集し, その頻度, 記事の食品群別分析, 容量, その内容などについて検討を加えたものである。健康と の関りについての記事は，937編中 $33 \% に$ 止まっており， 健康に良い, 㦟いの分析を加えた。しかし，マス・コミ に関する分析として欠けている点は, 揭載部位, タイト ル, 表現・内容の具体性, 写真や図, イラストなどの㨉 入などの分析を加える必要のある点が指摘された。

431 433（419〜421頁）座長 原一郎（関西医大） 431 : ペンゼン中毒は，今やわが国ではほとんど見ら れなくなったが, 高温・低栄恶状態では, ベンゼンの生 体影響が増大することが示され, 造血系の感受性増大に よるものと演者は推測した。実験方法などについて，川 上 (医霜大)，佐藤（山梨医大）と質疑応答があった。

432 ：有機溶剂の代謝に対する糖質負荷の影響を見た 一連の研究て, 溶剤以外の化学物質も検討の対象に加え られた。糖負荷期間の長短による影響の差異の有無につ いての質問（自治医大・野見山）に対し，代謝速度につ いては差がなかったとの，答えがあった。

433：モノクロナル抗体という新しい技術を用いた意 欲的な研究で, 血液・脾の $\mathrm{T} ・ \mathrm{~B}$ リンパ球を分けて, そ の動䈚を明らかにすることにより, 前年報告された抗体 産生能低下の機序の解明への前進が見られた。

434 438（422～426頁）座長 竹内联浩（名古屋大） 434 : 有機溶剖儤露労働者の血液検查成績と生活条件 の関係を検討した報告である。労働負担と検查成績とが 矛盾する結果について検查成縝が悪い者がこの業務から 除かれる為, 家事労俱を少なくしている, 蛋白摂取を增 していると述べているが, 検査結果からその様な健康指 票をしているのか, 演者の推測なのかとの筫問に対し て,この職場は 3 年間継続して健康管理をしているの て、指導の影雷を考えていると解答された。 435：有機溶剂作業者のリンパ球の機能と T 細胞サブ 
セットを検討した報告である。白血球数は軽微なストレ スで変動しやすい。この報告で白血球数に有意差が認め られているが有機溶剂の影慗と考えるのかとの質問に対 して，問診の時に風邪などのチェックをしており，他の 条件はできるだけ排除したと解された。ベンゼン曝露の 有無についての質問に対して, 尿中フェノールは測定し ていないので確答できないが，環境測定ではベンゼンは 検出されなかった。以前には $2 \sim 3$ か所でベンゼンが使 われていたがこの調查時には使用されていなかったと考 えると解答された。

436：トリクロルエチレンとその代謝物の膀胱からの 再吸収に関する実験研究の報告である。膀胱からの再吸 収は聞いていない。機序はどう考えるのか, 他に再吸収 の例はあるのかの質問に対して，膀胼の上皮細胞間の夕 イトジャンクションから吸収されるのではないかと考え ている, 䎵尿器科では膀睄に抗がん剂を入れると血中抗 がん剤濃度が上昇することが知られていると解答され た。

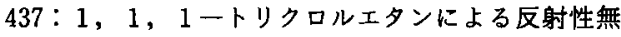
呼吸の実験研究の報告である。3.8\%は十分麻醉にかか る高濃度であり,一過性の無呼吸が急性中毒による死亡 の原因と考えられるのかとの質問に対して，短時間の死 亡の原因の一つとしてこの機序が考えられるのではない かと解答された。

438：1，1，1ートリクロルエタンの肝チトクロー ム $\mathrm{P}-450$ 系に対する uncoupling 作用についての実験 研究の報告である。この実験で消費酸素モル数が発生し た $\mathrm{H}_{2} \mathrm{O}_{2}$ に比して大きいが in vitroで実倹したらもつと 一致するのではないか, この差異の原因としてカタラー ゼの関与は考えにくいのではないかとの質問に対して, in vitroでも実験したが差異は変わらなかった，カタラ 一ゼの関与は考えにくいと解答された。

\section{442（427～430頁） 座長 石津澄子（東京女子医} 大)

439：障害をおこした肝葴に抱水クロラールを投与す ると TCA 産生が滅少するのは anoxia が関係している と推測し, 肝灌流液中に $\mathrm{N}_{2}$ や $\mathrm{O}_{2}$ ガスを流して, TCA，TCEの産生の変化を観察した報告である。この 発表に対し，TCA 産生の減少を anoxia を原因とする には問題があり，他の要因を考虑すべきではないか？ (東京医歯大・高野)， $\mathrm{N} 95 \%, \mathrm{CO}_{2} 5 \%$ 灌流液中に流 すことはかなり苛酷な条件ではないか？(埼玉医大・氏 名?）などの意見が出された。
440 ：農薬散布者の全身にどの程度農薬が付着しど の程度吸収されたかを衣服及び，尿について分析した結 果の報告で，経皮吸収が意外に大きいことに対し，注意 を喚起したものである。質問は出されなかった。

441：4 種の有機燐化合物をラットに投与し, 分泌唾 液量の時間的推移を検索し，アトロピンやPAM の奻果 についても検討している。質問は出されなかった。

442 : ラット，マウスのコリンエステラーゼ活性の測 定法につき，従来の方法を改良し，簡易化した報告てあ る。

この発表に対し，従来の方法と本質的に異なる点につ いて，（女子栄爑大・河合）またラット，マウスの性差 について，(東京歯大・山中）の質問が出された。

443〜446（431～434頁）座長 西村正雄（東京歯大） 443 ：橋本ら岋除草剤の DCPA 乳剤をマウス皮应に連 続放布した際の毒性を報告した。これに対し座長より， DCA は作業者にアクネを発症した経験をもっているが， DCPA ではどうかとの質問に対し，橋本は今回の報告 ではアクネと異なるが，毒性では DCAより低いとのこ とであった。

444 ：松下らは化学物質による皮成感作能の試験方法 を標準化しようと意図した報告であった。座長より試験 物質として maneb (manganese ethylenbisdithio carbamate）を使用した理由を質問したが，演者は農薬の殺 菌浏として多用されているので代表したとのことで，今 後例数を増す予定とのことであった。さらに座長より国 連の IMOの委員の 1 人より，日本からの農薬の申請て マウスの皮成刺戟性および感作性の成䍃が多い理由を聞 かれたことがあるが，それを裏づける意味でも今後の進 展を期待すると発言した。

445 ：曼尾らは前回の報告に引き続いて，TDI を塗布 したマウスの血清に specific IgG が出現するとの報告で あった。これに対し座長より図 4 の dimer の部位出現 は写真で明らかでないがとの質問に対し，No. 2，3， 11であるとの答であった。また，大前（慶応大）より TDI の経気道吸収でも同じかとの問いに対し, 石津（東 京女子医大）より，今回実施していないが，ほほ同じて あろうとの意味の説明があった。

446：奥泉らはTDI 暴露およびそれ以外による鼻アレ ルギー症状を呈する作業者の甥汁成分の泳動像との間に 共通のピークを認め, しかも TDI 喘息鼻アレルギーモ デル（モルモット）でも共通性があるとの示嗳に富んだ 報告であった。長尾（東京女子医大）上りチャトピーク 
はいずれも同じであるかとの質問に対し，報告者はピー ク4の場所が同じであると，また大前（度応大）より作 業者およびモデルの售汁による検査は毎日実施している のかとの問いに対し毎日実施していると答えた。また池 田 (東北大) より追加があり, 渿器の TDI 笙布作業は木 の下地珤りに使用されるものであると述へた。

\section{449（435～437頁） 座長 池田正之（東北大）}

447 : アクリルアミドの神経毒性を説明する仮説とし て解糖系酵素の阻害を考えることの妥当性について, 各 種誝導体を用いて検討した結果, in vitro の実験系では 否定的な成績が報告された。さらに共同研究者の橋本か ら, 今回は in vitro の成績を報告したが in vivoでもほ は同様の成績を得ている旨の追加があった。

448：アミノフェノール投与時に認められた血液・肝・ 腎のGSH 滅少の機序について討議があり，アミノフェ ノールとGSH との結合による低下のほかに，GSH 合 成系の阻害が起こる可能性が指摘された。

449: 対照者の中には過去 5 年以内に自宅の白蟻駆除 を受けた人が含まれており，その人の值は駆除を受けて いない人の值よりも相対的に高值である旨の追加があっ た。また皮脂拭き取り法は非観血的なサンプリング方法 として注目されるが, 各種テータから信頼出来ると思わ れる旨の追加があった。白蟻駆除に伴うクロルテン懪落 および環境污染の可能性については広範なモニタリング を必要とする重要なテーマと思われる。

450～452（438～440頁）座長 橋本和夫（金沢大） 450 : PCB の肝毒性, とくにポルフィリン代謝障害の 機序に関する動物実験の成績が示された。PCB 中毒、 ウスでは肝に URO genの蓄積が認められるが，この大 部分は肝内で非酵素的にUROに自動酸化されている。 この原因として，PCB 中毒に伴う脂質過酸化物の增加 を想定し，これにつき現在検討中であると述べられた。

451 : 油症に拈けるライスオイル食用回数と総死亡率 及び悪性新生物死亡率との相関が，“重みつき”回㷌分 析法によって検討された。患者のオイル食用回数と悪性 新生物, とくに肝の悪性新生物との間に，有意の量一反 応関係が成立する。SMR を用いての回帰分析法が問題 となったが、これには多少の危険性があるとの指摘があ つた。

452 : 職業性 PCB 污染者 2 グループの血中 PCB 濃度 の経年変化について報告された。いずれのグループにお いても, 血中濃度は有意に隇少を続けているが, $\mathrm{PCB}$
組成の推移では, 低塩菜化成分の減少がある一方, 高塩 素化成分含有率は增加傾向が認められた。血中 PCB 量 は, 体内脂肪組織中に蓄積している PCB 量を推定する ための指標となると述べられた。

501～504（205～208頁）座長 梨本一郎（埼玉医大） 501 : Paul Bert（1878）以来酸素中毒に関し多くの研 究がなされており，本演題内容に類した病理学的研究も 少なくない。あえて実施した意図について，演者は活性 酸素との関係を知りたいためとしているが，この結果か らは、そうしたことは見出せないはずである。また肺に 対する毒性量 (UPTD) との関係について質問があった が、とくに回答はなかった。

502 : 活性酸素ラジカルの湘定に関して，スピントラ ップ法は強力な研究手段であるが，一歩誤ると無意味か または間違った結論を導くことが少なくないとされてい る。この実験ではトラップ剂の DMPOの精製を全く行 つておらず，計測值が果たして OH ラジカルのみを示 しているか大いに疑問との指摘があった。また高気圧酸 菜中よりも減壬後に高い值を示す理由について明快な説 明はなかった。

503 : 萡水用レギュレータは元来水中で使用するもの て，呼吸生理学的筧点加らその評価は水中という実験条 件が欠かせないはずである。また呼吸に対する負荷は圧 量図によるへきで，酸素消蔶量は空気中と水中では大へ ん異なり指標にならないとも指摘された。

504：内耳压・外偒に関してモルモットを使った実験だ が、A 群に比し B 群は，また A 群に比し C 群は有意に 障害が大きいとしている。しかしながら有意差を云々す るとき, 危険率を付記するのは統計学のイロ八であり何 故記述しなかったのか理解に苦しむ。

505～508（209～212頁）座長 万木良平（防衛医大） 505：酸素欠乏や污染空気環境下で安全に酸菜を供給 するために考案された循環式肺力型呼吸装置の試作品の 機能を, 労作時と安静時について検討した結果の報告て ある。 $\mathrm{CO}_{2}$ 吸収キャニスターに連結された呼吸袋が呼 吸筒内に組み込まれ，その圧変化を利用して必要量の $\mathrm{O}_{2}$ を供給するのが特徴であり, 最初は一定時間 $\mathrm{N}_{2}$ 洗 い出しを行う等の配虑をすることにより実用化の可能性 が示唆された。装置の機能や実用化と実験方法の改善等 につき有益な討論が行われた。

506 ：CO 中毒やシアン中毒に際し重要な anoxia によ る細胞レベルの機能障害の可逆性・不可逆性の限界点へ 
の $\mathrm{Ca}^{++}$の関与につき，家鬼尿細管細胞浮遊液を用いて 検討した結果の報告である。細胞外液の低 $\mathrm{Ca}^{++}$条件は 機能的呼吸障害に影䪪を与えず，ミトコンドリアの回復 に不利であるが, 全体的細胞障害の発現を軽減させると 推論した。尿細管細胞を用いた理由，僅かに残存する $\mathrm{O}_{2}$ の影翌等につき討論が行われた。

507 : 減压ストレスによる微小循嘪の変化に関し, 演 者らの教室で従来行ってきたハムスター敇袋による研究 に加えて, ラットの脂肪組織について検討を加えた結果 が報告された。gas emboliの出現と微小循環障豈は基 本的には両組織間に相異はないが, 各組織の特性に応じ た障害のあらわれ方に特徵が認められた。瀻器組織別の 减圧症発現機序等につき有益かつ活発な討論が行われ た。

508 : 演者らの教室で超音波断層装置を用いて行って きた隇圧症の血行性気泡の検出法の研究成果を, 実際の 圧気作業者に応用して, 減圧終了後に観察測定した結果 の報告である。ビデオ収録した画像を検討した結果，心 室内気泡像が鮮明に認められ、ドプラー法の気泡音確認 に比し気泡の grading が容易で評価の客翼性がたかめ られた。判定の standardization, 减圧症の予防・治療 への応用等につき有益な討論が行われた。

509 512（213～216頁）座長 山田信也（名古屋大） 509 : 東京都監察医務院の記録 (昭和53年より 5 年間83 件）から，凍死例の実態分析の報告である。酪酸による 屋外での涷死が多い。質問への答で, 注目すべきもの に, 浮浪者の屋外睡眠での死亡, 独居老人の自宅での暖 房のない生活中の低体温症による死亡, 親が乳児を放置 したための死亡があげられた。この件数と原因の特徵 は，歴史的にみてどうなのかがひき続いて検討されるこ とが期待される。

510 : 高血圧状態の寒冷暴露による反応変化が, 自然 発症高血圧ラットを用いて検討された。低温下で震えの 発生が対照より大きいにもかかわらず直腸温が対照より 下がりやすいことが指摘された。人の場合についての臨 床検討例が少ないと述べたとに対し，高血压であっ て, 屋外の寒冷環境で昼間のみならず夜間も就労してい る人は実際に存在し, 夜間では, 降圧剂の服用がなく, 血圧変動がめだつことがみられるので問題が大きく，夜 間作業中死亡して問題となった例もでており，そうした 対象を調查されるようにという期待が会場から出され た。

511 : 救難用耐寒酎水服の性能について, 人体及びマ
ネキンによるテストが 2 種類のイマージョンスーツにつ いて30才代の被検者 3 名に関して報告された。6 時間 0.5 0.7 $7^{\circ} \mathrm{C}$ 水水槽内の成績は良好であるとの報告に対 し，30才代の健康男子に比して体力の劣る年令の高いも のでのテストの必要性が指摘された。また, マネキンの 人体シュミレートが熱収支のみに関して可能であること に対して，その規格化や他の機能のシュミレートの可能 性が質問された。現在の段階では，サーマル・マネキン のみについて, 委員会でとりきめられていること, 他の 機能については，いまだ手がついていないことが答えら れた。

512 ：前の演題は，商船を対象としたIMOの勄告に こたえるものであるが，漁船にはこの勧告の適用がな い。現実には冬季の北洋漁業で転覆による死亡が多い ことから運輸省は， $5{ }^{\circ} \mathrm{C}$ 水中 1.5 時間を限度とした規準 をつくってイマーションンーツの実用化をすすめた。本 報告は,この試作品の性能が19才 3 名の被検者で 2 品種 について報告されたものである。これに対し，漁船の従 事者の平均年令（答・48才）は高いことから高令者でテ ストする必要，1.5時間は短くないかと質問された。1.5 時間の限度は，実際の救助例は，釧路・函館・焼津から 1.5時間の筙囲，北洋では，視界内の網打作業時なら 1.5 時間で達しうることが根拋であると答えた。漁船の場 合，商船に比へれば軽易なもので，普及に重点を置くと いう考えも含まれているのかと感じたが，北洋漁業の儀 牲のないような早急の対策が望まれる。

513 516(217 220頁) 座長 永田久紀(京都府医大) 513 : 運動時の生理反応に及ほす湿度の影響をとくに 男女差に重点をおいて実験的に㭘討した結果が報告され た。石川（千葉大）から被検者の高温馴化の状態， Evapotative Heat Loss, Heat Storage の男女差などに ついて質問があった。

514 : 消防隊員の至適な休息時間を検討する一助にす るために, 消防庁の特別救助隊員を被検者として運動負 荷実験を行った結果が報告された。実際の休息時間設定 には自覚的評価と他覚的評価の両者を考虑する必要があ ると述べられた。

515 ：野球審判員の生体負担を実測した結果が報告さ れた。石川(千葉大)より現境条件の評価にWGBT を用 いることが望ましいとの希望が述べられた。尿酸值の上 昇の原因などに関する質問もあった。

516 ：演者が菊池に変更となった。3 科の温熱環境下 て飼育されたマウスの血中コルチコステロン呈，末梢り 
ンパ組織中の丁細胞サブセットについて報告されだ。週 踰 $4 \mathrm{~W}$ のマウスを用いた理由, 馴化期間を 3 週間とし た理由などについて質問があった。また， $36.5^{\circ} \mathrm{C}$ 飼育の マウスのコルチコステロンは高値を示すが日内変野の様 相には変化のないこと, 馴化温度と日内変動のパターン 等について討論があった。

517～520（221～224頁） 座長 松下敏夫（鹿览島大） 517 : 菅原 (大分医大) から, (1)毛細管法の場合血液と 墨计がうまく混和するか, (2)管内のコーティングの有無 が筫問され，(1)血液が少ないと混ざりにくい, (2) Ht 管 を使用していると答えた。

518,519 : 坂本 (三重大) から貪食能と $\mathrm{O}_{2}$-と平行す ることの解秎が質問され, receptorのところへ行けば $\mathrm{O}_{2}^{-}$を出すと考えられていると述へた。座長から Fig. 2,3で形が異なるのをどう考えるか，高野（東京医歯 大）から $\mathrm{O}_{2}$ 消费量が増すと思うが limiting stepはない かが䨘問され, 前者は現在のところ不明, 後者はこの位 の算度ではその心配はないと答えた。興味ある研究であ り、今後の発展を期待したい。

520 : (1)平野 (公害研) から呼吸数はどうなるか, (2)座 長から脈拍数などの測定は行っているか, (3)高野（東京 医䨑大）から呼吸深度は $\mathrm{CO}_{2} \uparrow に よ り$ 生したと考えてよ いか, (4)荒木（埼玉医大）から採血のシリンジの取り扱 いと測定時刻の関係などが質問され，(1)呼吸量の增大が ある, (2)湘定していない, (3)まだ結論を得ていない, (4) 引く速度を一定にし，安定したところで測定しているな どと答えた。

\section{524（225～228頁）座長 福岛一郎（順天堂大）} 521 : マウス個体群が異なる環境下におかれた時の行 動様式の変化を見るため, population cage $\left(1.5 \mathrm{~m}^{2}\right)$ を 作製して,この open fieldに小ケージ14個をパイプで 接続して飼育した結果が報告された。エサ，水の量を制 限すると，100日目以降は妊娠はしても新生仔が認めら れなくなる事実や, open field 大小の居住空間に区切 ると, 小空間で飼育した群にジャンピング行動や open field 内での授乳行動が早くから認められる事実が発表 された。山口（昭和大）から，異状行動をとるマウスは 特定の個体か, との質問に対し，そうではないとの回答 があった。

522 : 誌上発表。

523 : 生体反射分光法によるラットの体表反射スペク トル湘定から流血中 $\mathrm{COHb}, \mathrm{MetHb}$ の生成・消失を連
続的に測定する方法を開発した旨報告された。高野（東

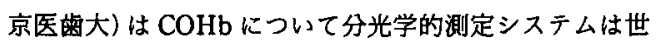
界で初めてであろうと評価し，スリット幅をどう設定し

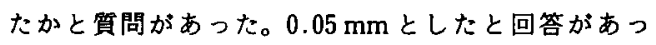
た。

524 ：健康㛿人の月経時における黄色フドウ球菌の检 出成績について発表された。藤原（筑波大）から, 月経 中の健康婦人の使用した紙ナブキン中のブ菌の他, 腸内 細菌については調へたかと質疑があった。生菌数は調べ たが，腸内細菌は今回調へていないとの回答があった。 臨床由来材料について得られたブ菌30株から TST 産生 株を 1 株見出したとの報告について, 座長から材料の種 別を質したところ，大部分が尿であるとの回答であっ た。

525〜 529（229～233頁）座長 奥田久徳（広島大）

525 : 好塩基斑点赤血球出現因子の追求を目的とする 研究報告であった。ハブ毒の作用は, 鉛中毒や皮凰障害 の作用とは，作用機序が異なることが指摘された。毒性 学的あるいは病理学的に興味深い報告だと思われる。

526 ：強力な人工紫外線を用い, 種々の細菌を殺菌す る際の蛋白質共存の影響を実験的に検討した報告であっ た。蛋白質の物理的性状などが討論されたが, 食品の殺 菌などに応用性があるとのことであり，今後の研究の発 展が望まれる。

$527 ：$ 金属銅や銅塩のヤブ蚊幼虫駆除奻果を実験的に 指摘する報告であった。基地の花立てなどに応用すれ ば，筬便な方法として役立つことが期待される。なお， 北原名誉会員から，木灰を利用して水をアルカリ性に し，力の発生を防ぐ報文があることが追加された。

528 : コインドライクリーニングの利用者の有機浴剤 暴露状況を実験的に検討した報告であった。利用者が高 濃度の有栐溶郕蒸気に暴露される危険があり得, また洗 灌後の衣類中には多量の有機溶郕が残存することが指摘 された。衛生指学の徹底を望むという演者の主張は重要 たと思われる。

529 : 森林浴の健康増進効果に関する実験的検討の報 告であった。高浇度の $\alpha$ ーピネンに対する暴露によっ て、マウスの免疫応答性が高まることが指摘された。社 会的関心の高いテーマであり， $\alpha$-ピネン以外にも種々 の条件の関与が考えられるとのことで, 今後の研究の発 展が期待される。

530 533（440～444頁）座長 晋原和夫（大分医大） 
530 ：身長の伸びは身体各部位が均等に伸びたのでは なく，下肢長の伸びが著しかった。その中でも特に身長 の高い群にその影響が大きかった事を、この20年間の瓷 料をもとにして明らかにした。

531 ：体容程を従来の水置換法にかわり，空気置換法 により求めようとする新しい試みであるが，空気の物理 的条件のコントロールに今後の問題があり, 水置換法と の比較検討が望まれた。

$532: \mathrm{HR}-\mathrm{VO}_{2}$ 法は個人の 1 日消費熱量の算出には不 都合を生ずるが，個人個人の $\mathrm{HR}-\mathrm{VO}_{2}$ 関係式を用い個 人差を消去すると菒団的評価には有効である。なお睡眠 時の代謝について，心拍数からみると従来いわれている 基礎代謝の0.9は今後検討を要する。

533 ：長期療普者の特に外気にあまりばく露されない 者の BMR が季節変動が認められた大変興味深い発表て あった。血液化学的にも健常者群との間に, 冬期夏期に 群差の傾向を認められ，長期療飬者の主として人工気候 的条件が季節変動の修飾要因であることを示唆した。

534 537（445～448頁）座長 豆田定䣡（東海大）

534 ：坂本（三重大）：万歩計の製品むらは，2 割以上 の誤差を示すものが $30 \%$ 程度もある。この点成績にどう 影響するか。答：このような誤差を含めても，万歩計指 針量とエネルギー消蒷量との間には予想以上に高い相関 が認められた。松本（杏林大）：事務職員で相関が高く, 機械組立作業者に相関が低いというのは逆のような感じ がするが。答：事務職員では，椅座作業の間にけっこう 歩き䞟る。機械組立には，各種の作業があり，また動く 時も万步計がカウントするような動きは少ないためでは ないかと考える。近藤（奈良医大）：今回の発表をきく と，主婦の行動量とエネルギーを測定するのに万歩計は 使えぬように受け取れるが。答：対象者の動作や労働の 様熊を十分知っていなければ使えないと思う。

535 : 谷島（日本大）：眼球運動はどのような方法でと らえるか。又，身体動摇についてはどうか。答：坂本， 眼球運動は角膜・網膜電位変化值をとり, 身体動摇は $\mathrm{X}$ 一Y 軸動摇の軌跡の長さを測定し, 皘分值で示す。追 加：姿勢反射が眼球運動と関係があるということは NASAでも同様の知見を発表している。追加：坂本， この研究の目的は, 疲労評価のための情報を得るうえ で, 各種の検査の測定条件を検討する一環として行った ものである。

536 : 補足：課題実施60分直後に色彩桿測定を行うと, 背景の白白壁がピンク色に見える割合は，陰画表示で93
\%，陽画表示で67\%であった。

$537 ：$ 松本（杏林大）：4つの変動パターンで多いのは どのタイブか。又, 従来の方法との比較はどうか。答： A タイプが最も多く6名で，次いでCタイプであり， B, D タイプは各 2 名である。従来法との比較はしてい ない。今後検討するつもりである。谷島(日本大)：図 3 と図 4 はどの基本型に属する例で，何例か。答：Cタイ プであり，1例のみである。

538 540（449 451頁） 座長 三宅浩次（札幌医大） 538 :VDT 監視作業及び筋肉作業を課して，フリッ カー值, 血圧, 選択反応数, タッピング数を剆定し, 別 に実験で得た回㷌式にあてはめて疲労度とした。この疲 労度の考え方について討議があった。質の違う作業をつ ルコール投与時の状態で統一的に报えるかという点で, 討議者間での合意は得られなかった。

539 : 新潟県下の特殊学校職員 (ろう, 盲, 養櫒) 930 名について，腰痛の訴えをアンケート調査したものて， 率護学校職員が訴え率が高く，その中でも男で教員が教 員外のものより高く，女でも教員・寮母・舎監が他のも のより高かった。日常業務での介護作業が多いためであ ろうという。

540 : 呼気中のペンタン漂度を測定することによって， 大気污染による呼吸器への影響をみる指標となしうるか を検討したものである。45名の男女の呼気中ペンタン濃 度と肺活量, 自覚症状の動悸や息切れとの間に関連がみ られた。ペンタンは体内ての生成と外部からの取り入れ の両者があるという。

541 544（452～455頁）座長 白谷三郎（弘前大）

541 : 名古屋市内に居住する高齢者スポーツ教室受請 者24名についての, 生活時間と日常生活心拍数について の調查報告であった。運動や散歩は平均15〜30分, 睡眠 時に対する賞醒時の平均心拍数は $25 \%$ 増のレペルであっ たので，これよりも高い心拍数レベルでの運動を日常生 活にとり入れることが望ましいとのべた。

542 : 運動時の血压, 心拍数を, 回復時の両值から推 定する式を提案した。年齢と，運動負荷回復後15秒加ら 30秒までの心拍数，回復した時の収縮期血圧から得た関 係式が最も有効とのことであった。ただ，運動により拡 張期血圧の上昇はみられなかったという本報告に対し， 渡辺（愛媛大）から，女子の中高年者では拡張期血圧の 上昇するものもあるのて，検討して欲しいという追加が なされれ。 
543 : 愛媛県で中高年者を対象として, 僄動処方を行 い,これの指䢥に当たった85名のうち，運動を継続した ものは20\%に止まり, 運動継䌇群でも血液化学的にやや 改善されたものの体力医学的には期待したごとき結果は 得られなかったとし，この種の教育の難しさをあらため てのべた。

544：24時間隔日交代制勤務者の睡眠状態について， 対照夜, 夜間仮眠, 昼間睡眠, 回復夜をそれぞれ脳波学 的にアプローチし, 若年者に比べ中高年者では, 夜間仮 眠，昼間睡眠でいわゆる睡眠が浅くなる傾向があること を示し, 夜勤に対する睡眠適応に年龄差があるものと推 湘した。

$$
\text { 545 548（456〜 459頁）座長 古見耕一（杏林大） }
$$

545：3 月間の持久性トレーニングによる最大下作 業時の交感・副腎餚質, 心瞒血管系わよび代謝系応答の

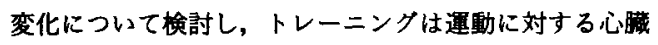
血管系応答の改善をもたらしたとする発表であったが, 演者の都合で共同研究者の代読であったため，2，3の 質問はあったが，あまり討議はなされなかった。

546 ：重回熼モデルによる生物学的年龄の推定が暦年 路と比較して過大または過小に評価される欠点があると して, 発表者らは判別分析によるそれを試み妥当性を莬 討した。しかしこの方法によっても変数の選択に関す る問題があるとする質問が出て,この方法も果たして適 当であるかどうか基本的に問題はないかなどの議論がな された。

547 ：東京都民約 22,000 人の健康診査资料をもとに， 赤血球数, 血色素量, 血圧などをはじめ一般的検査項目 10数種から重回啋分析手法を用いて Ageing の評価を椧 討している。結果は，今回の方法でも充分説明し得なか ったというが, 今後さらに変数項目の内容なども検討 し，また，種々の方法による検討が望まれる。

548 : 発表者らは70才以上高齢者と若年者について, $\mathrm{T}$ 細胞サブセットの量的変化を比較検討し, その意義 について推論している。今回は先記年代間のみの比較で あるが, 今後, 年齢階級別にさらに詳細な検討を行うこ とにより，老化指標の一つになりうるかも知れないこ と,また,より応用範囲がひろがるであろうなどの討議 がされた。

$549 \sim 552$ (460 463頁) 座長 木村菊二(労働科学研) 549 : 粒径分布の異なる 3 種類の石英粒子について, $\mathrm{X}$ 線回折分析を行い, 半価幅から有効不整格子定数, 結
晶子の大きさを求め, 粒子の大きさ, 熱処理前後の表面 樓造の乱れの程度などについて述べた。この報告に関連 して，粒子表面の活性に関して討議があった。 550 : 粒度の異なる 3 種類の石英粒子について熱処理 を行い，その粒子の色素吸着量を求め粒子の表面活性に ついて検討した結果を報告した。これに対し，熱処理の 方法と表面構造の変化などについての討論があった。

551 ：トンネル工事などの出稼ぎをしているけい肺患 者について尿中 HOP/creat 值, X線病型, 肺機能の測 定を行い，䝟煙などとの関連について検討した結果を報 告した。尿中 HOP/creat 值は，けい肺患者と対照者と の間に有意の差が認められるが，喫煙量との間には，は っきりした関係は認められなかった。この結果に関して 若干の質疑があった。

552 ：トンネル工事に従事する労働者の多くは出稼者 であり，その供給地域は全国に散在している。その労働

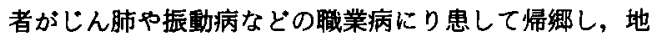
域保健上の重要な問題となっている。本報では出稼労働 者の代表的な供給地域の一つを選び地域全体の出稼実態 について調查を行った結果を報告した。これに対してト ンネル工事の環境条件や保讙具の使用状況などについて 若千の討議があった。

601 603(234 235頁) 座長 今村 晋(東京医歯大) 601 : 京都市の感染症サーペイランス事業と京都市公 费負担制度のそれぞれにおける報告数の比較をおこなっ て, 疾病の把挃率を検討し, 基準疾病としてMCLSを 用いてのデータから, 小児感染症の年間患者数の推計を おこなった。ただし，感染症の基準疾病として MCLS を用いることについての問題点の指摘があった。

602 : 長崎県におりる 5 年間の感染症サーヘイイランス の通報状況の推移をまとめたもので, データの考察に際 しては, 通報定点の規模などについての検討が必要であ る。麻疹の予防接種の効果に関しては, 接種時期を早め る事についての討議があった。

603：東京都における感染症サーペイランス事業での 定点観測データについて, その周期的特性と環境要因の 特に気象との関係を麻疮, 水痘などについて調べた。気 象の観測データは東京都の各地で一様ではないので，そ の点の検討について質問があった。

604 608 (237 241頁) 座長 川井啓市(京都府医大)

604 : 別海町の成人女子の風疮感染の血清学的追跡調 查は中園（北海道大）の発表によるものであったが，こ 
の問題は先天性風疹症候児の出生といった社会的に大き な話題であり，これから国家的に対処されるべきもので ある。またそのための基礎的資料として評価出来るもの であっだ。

尚,この演題と軌を一つにしたものに606席の鳥取大 学の陶山の発表があった。即ち「地域における風疹対策」 を問題にしたものであるが，604席とともに風疹予防ワ クチンの接種にともなう費用効果をも検討したもので， 今後の施策のなかで生かきれる研究と思われた。

605 ：菅又ら（帝京大）の日本脳炎，麻疮および風疹ウ イルスに対する抗体保有率の検討では, 出生季節に差が みられたとの興味ある報告であった。問題は母胎に対す る注射の影霎がみられている可能性を否定出来ず，この 時期の何らかの漫育が胎児に免疫寛容を成りたたせてい るのでなかろうか。

607 ：中園ら (北海道大) の東アジアにおけるアデノ. ウイルス性結膜炎のサーウエイランスを札幌, 徳島, 高 雄, 至山との間で分る疫学的解析を武みたものである。 今後ともこの手法は地理病理学的展開において重要とな ろうが，まずマクロの立場からの所見の把握が望まれ る。

608 : 今村ら (東京医歯大) のレプトスピラ症に対する 薬㓩の感受性を実験動物としてのスナネスミ応用に関す る継続的な研究であった。ヒトとの共通性・非共通性の 整理の上にたって薬剂感受性の効果的な研究には試獣の 応用は必須である。

609〜612（242～245頁）座長 浦沢正三（札幌医大） 609 ：晨崎県下の地域別各種肝疾患死亡率（全国を100 とした SMR）とHB 抗原陽性者率の検討。これらの率 が䧳島などで高率であることについては，自宅分婏率と 抗原陽性率の相関の存在などから出産時感染を含む生活 環境条件の地域差存在の可能性が論議され，地域毎の抗 原陽性率と死亡率の相関の検討に関しては，前者を長期 間不変な地域の特性値と見なし得るか, 地域別の比較に SMR を用いることの意味などについて質疑がなされ た。

610 : 猿島肝炎の流行をみた猿島町内の流行地区と非 流行地区におけるその後の定期住民健診の検查成喘か ら，上記流行の現在への影䇾を評価検討した第 3 報。長 年の調査結果を今後の住民への対策にどう結びつけるか の視点での発表が期待される。

611 : 肝疾患罹患率の高い岛根県の一漁村における疫 学的研究の第 4 報。主要な 3 医療機関で把挃された肝疾
患患者を対象に，郵送質問紙法により患者のその後の生 活上の留意事項などを調へた結果, 多くの者が日常生活 上肝疾患に留意し，かつ肝蔵检診を望んでおり，地域住 民に対する 3 年間の疫学調查, 健診活動が成果をあげて 来ていることが報告されると共に，HB抗原陽性者に対 する指遄内容について貿疑がなされた。

612 : 近年因果関係の有無が裁判において争われるこ とが多い。佐賀県基山小学校で流行した A 型肝炎（基山 肝炎) は，难患住民による損実賠供請求裁判においてそ の原因は樭便中のウイルスによって污染された井戸水の 飲用によるものと判断されたが，裁判でこの様な結論に 至った疫学上の事実とこれに対する反論などについて報 告された。

613 618（246〜250頁）座長 钉本 完（信州大） 小児保健における発育問題は最も重要なテーマの一つ て, 今学会においても小児保健17演題中直接発育に関す るもの 8 題，さらに発育に関連をもつと考えられるもの を加えると約 7 割を占める。

613：細胞増殖因子である生理活性ポリアミンを幼児 期の発育との関係でとりあげたもので, 湘定法の確実 性, 再現性等よりみて今後の展開が期待される。

$614 ， 615$ : 同じく幼児期の発育問題につき 1 つは永久 歯萠出の面から，他は乳歯のウ蝕歯の面から検討したも のである。今回の発表はいずれも出生月別に検討したも のであるが，両者ともその関連が認められた。とくに後 者の関係は明らかで, 妊娠中母体の健康管理の必要性を 考えさせられる。

616，617：小児，思春期に関連した報告である。616 は小児より思春期に至る間の発育速度を体重について求 め, その分析から発育のスパート時点 Sを設定, これ と初潮時 $\mathrm{M}$, 身長, 体重, 皮脂厚等との関連を述へた もので, S 点による発育問題へのアプローチは甚だ興味 がある。

617はきわめて長期かつ大量の初経資料について, 平 均初経年令, 出生月別初経年令, 初経発来月等の年次推 移の状沇をまとめた貴重な報告である。近年この種の報 告をみることが少なくなった。学会としても今後さらに この方面への努力が必要でちう。

\section{8～620（251～253頁） 座長 三浦悌二（帝京大）}

618 : 松本ら（和歌山医大）は，身長の最大発育年粹 (MIA）の若年化に見られた地域差の原因を求めるため に, 県民所得, エンゲル係数など21項目の社会・経済指 
標との関係を調へて，都市化と平行するような要因が関 与しているものと考えるに至った。

619 ：左ら（和歌山医大）は, 暲国人の MIA を調べ, さきに，日本より遅れて若年化が始まったことを報告し ていたが, 今回は, 大都市の金山では若く, 中小都市て 幄れていること，概してMIAの年齡が，日本よりは少 し遇く、欧米よりはやや早いことを示した。

620 : 小西ら (和歌山医大) は，運動能力の発達が最大 になる年齢を個体別に求めて, 21例から, 運動の種類に よって異なり, MIAより若いもの（垂直跳び）と, 遅い もの (50 m 走) とがあるが, 両者を仕事量として, 換算 して表現すると，ほほ同じ時期となり，MIAよりもや や迤い時期にピークのあることを示した。

$621 \sim 624$ (254 257頁) 座長 吉田度久 (大阪医大)

621 : 乳幼児健診のパーソナルコンピューター処理導 入において, 初心者でも早い時期に実用化できる简易言 語の利用に意義がある。この場合, 保健婦が使うとして その意見を入れて定式化を進めよという凟成と，一方， 人対人のサービスの低下，プライバシーをどうするかと いう傎重的な発言もあった。

$622 ：$ 現在でも二次疾患や機能障害の誘因となる扁桃 肥大について学校保健の立場から行った調查である。疫 学的調查についての質問で, 家族集積性は認められるも のの, クラス集積性は未調査とのことであった。扁桃肥 大減少の要因として, 体位の向上, 診断基準の推移, 開 業医の手術回避などが反映するものとの追加があった。

623：脂貝代謝に重要な倠きを有すとして最近特に注 目されている血清アポリポ蛋白實 C II の分布について, ます脸血管疾患の出現頻度が全国平均の $2 \sim 3$ 倍高い対 象地区について，特に従来少ない小肾期のデータを明確 にするものとして意義がある。なお表 1 の被検者数につ いては本文中の方が正しいとする訂正があった。

624 : 従来より行った疫学的研究を基礎に, 増加する 肥满児対策としてきめ細かい指等基準をつくり，現実に 学校現場における保健指晸を行って，その有効性が実証 されたことは意義深い。特にスポーツについても，行う ことに喜びを感じさせるなど積極的な方法がとり入れら れている。賢問として，両親とも肥満など背景要因につ いて，その印象ありなどのほか，被険者数290名を131名 とするよう訂正された。

625～629（258～262頁） 座長 華表宏明（産業医大） 625 : 福岡県某市の12の中学校中11校の生徒を対象と
した，喫煙についてのアンケート調査の報告である。哭 煙防止教育の基礎資料をうる目的でおこなわれており， 今後きめのこまかい解析と具体的な教育についての方策 が検討されることが期待される。

626 : 曼野県下の小, 中, 高校生7,000人余りを対象と した，貧血についての血液検査と，スポーツ活動などの 生活実態についてのアンケート調査の結果との関連性を 検討している。成長期にある子供たちの各時期に応じた 対策が生まれてくることを期待したい。

627 : 高知県下で1973〜83年に注意集中障害览として 診断された157人の小，中学生を対象とし，家庭およひ 学校へのアンケート調査をした結果についての報告であ る。これから，その頻度, 実情などについての記述疫学 的な基䃈资料が蓄積されていくことが期待される。

628 ：鹿児島県下の中学校の教科体育時に発生した547 件の報告事故を対象に, 事故の発生状況を中心に, 検討 した結果の報告である。これから、さらに報告されなか つた事故を含めて，予防対策につながる具体的な教育方 針がうち出されていくことを期待したい。

629 : 奈良, 大阪の 6 小学校における坚童 300 人余りを 対象として, 骨折経験の有無と生活実態との関連性を追 求した報告である。さらに, 男女別, 低学年, 高学年別 にくわしく生活実態との関連性が検討されていくことが 期待される。

630 632 (464 466頁) 座長 松本信雄（㤎恵医大）

630 : 既報のアナフィラキシー・ショック時に奇形が20 \%発生したという実験結果より, 今回はヒスタミンの作 用に注目した報告で, 奇形の誘発における量・反応関係 が強調された。遠藤（山形大）より奇形の種類が二つの 実験間で差があったか否かの質問があり，これに対しほ 沺同様であると答えられた。

631：“染色体異常発生の季節変動”ては小野沢 (慈恵 医大）より変動ありとする報告の有無の問に対し，A 型 肝炎流行との関連で変動ありとする報告があるが, 気 温・気圧などについてはみられないと答えられた。日暮 (山梨大) より人工流産の適応如何の問に対し, 全部社 会・経斉的理由によるものであることが示された。

632 : 日暮 (山梨大) より染色体異常型の観察に用いた 細胞数・分裂指数について筫問があり，前者では約 1,000, 後者は20〜30\%である旨答えられた。岡本(鳥取 大）ょり，七ト由来細胞の自然悪性化・in vivoでの当該 物質の腫掦の誘発の有無についての問いに関しては, 今 後の検討が期待された。 
633 636 (467 470頁) 座長 山本正治（新潟大）

633 : 化学物貿 4-Nitroquinoline 1-oxide (4NQO) の マウス妊娠早期胚に及ほす影響を in vitro で調べた報告 である。染色体異常, 姉妹染色分体交換頻度の增加とと もに，移植後生存率低下、発育低下を認めた。4NQO は代唧活性化が必要な物質であるので，処理した時期の 卵の代謝系について賽問があり，この間の事情について 意見交換があった。

$634 ： 1978 \sim 82$ 年間に都立11産院で出産した児につい て先天異常を調查した報告である。先天性水頭症, 気管 食道瘦，尿道下裂などの発生に時間集積性があったと報 じている。この点に関して, 我が国における他機関のモ ニタリングシステムで同様の変化を同時期に確認してい るか否かについて質問があった。

$635 ： 1972$ 年以来行われている我が国最大の染色体異 常モニタリングシステムについての報告である。常染色 体異常の発生頻度は欧米の諸家の報告と差を認めなかっ たとのことである。しかし，性染色体異常（XOおよび そのモザイク）頻度に差異が見られることに対して，こ の観察システムでは, その全例把暒が困難なことについ て意見交換が行われた。

$636:$ :トの先天異常発生の性差について動物モデル を用いて検討した報告である。biotin 久乏の妊娠マウス では口蓋裂発生が雄に多いが, cytosine arabinosideて は性差を認めなかったと報じている。作業仮説として胎 仔の精巣からテストステロン分泌の可能性を示唆したの に対して, 口蓋裂発生の臨界期とテストステロン分泌時 期について軼問があった。

637 640（471 474頁）座長 遗藤 晃（山形大） 637 : スタッフは何人か, との質問(東京医大・羽生田) には，直接は演者 1 人で対応しているとのことであっ た。次子を希望する夫㛿が意外に少ないようだが，どの ような態度で親に接しているか（山梨医大・日暮）との 問いには「次子には心配ないと話しているのだが話し方 を考える必要があるかもしれない」との回答があった。 638 : 図 3 と図 4 が逆になっている，との訂正があっ た。cost-benefit の観点から採算はとれるのか, との問 い（山梨医大・日暮）には, 試薬・人件唄を入れて 1 人 あたり100〜130円とのことでった。

639：カットオフ値をどこにおくべきかについての質 疑応答があった。また,このスクリーニングは, 検查時 に異常なくともその後に発症することがあり検査時期が 大切である，とのコメント（山梨医大・日暮）があった。

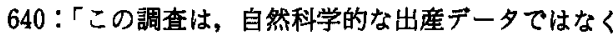
洗礼記録を秶料として使っているが，その点問題はない か」(弘前大・佐々木）との筫問には，検討していないが 問題があるかもしれない, との回答であった。

641 644（475～478頁）座長 村上 兔（神户大）

641 : 分婏時異常出血を予知する目的で, リスクファ クターを分析した結果, 胎児の大きさや産道の狭さのほ かに, 初産, 異常出産, 帝王切開, 線溶系などで有意な 相関を認めたという報告に対して，分婏法の選択や分婏 時の処置の違いによって結果が変わるのではないか, 胎 児の大きさに関連する在胎日数に有意性の認められない のはなぜかなどの㗨疑が交された。表 3 の分婏時間櫚の 空白部には，表の左から $1,3.762,2.79,0.087$ デー 夕が追加された。

$642 ， 643:$ 低出生体重児と成熟児の両群を比較し，身 長, 体重, 胸囲, 座高のいずれについても小学校在学中 のすべての時期で両群には有意差があるが, 初経時年齢 には有意差を羿めず，初経時の体格には乳児期の授乳方 法も関連していることが報告された。低出生体重児でも 3 葴ぐらいで対照児の体格に追いつくという発言に対し て, 本調查では $2 \mathrm{~kg}$ 末満の出生児を選んているため両 群の差が樎まらないのであろうと回答された。長期間に わたる観察は有意義であるが，データをもとにどのよう な主張が意図されているのか, あるいは実態を数值て表 現することのみが調査目的なのかについても言及してい ただきたかった。

644 :出生時体重の過大または過小には, 妊娠中の精 神的身体的社会的要因よりも両親の体格に関連の大きい ことが示された。流早産の危険をより具体的にとらえる ための工夫，若年と高年の妊婦に高い未熟児出生率の因 子分析, 両親とも体格の小さい場合や母親のみ小柄な場 合の出生児の体格などについて，さらに検討されること を期待したい。表 1 の出生率で86.6は68.6に訂正され た。

645〜 648(479 482頁) 座長 需山光子(名古屋市大) 645 ：国際的にも多大の関心がもたれているアスペ ト粉じんについて，幾つかの事務室内における測定結果 を報告したものて，田中（昭和大）から湘定場所による 濃度差について筫問があり，建築年数との関係もあるの ではないかとの回答があった。今後更に詳細な研究の行 なわれることを期待したい。

646 : 室内上下気温差による人体影響を下半身部を異 
なった気温状況においた場合について行ったもので，奥 田（仏島大）よりボックス内の湿度，気流について婜問 があり,人工気候室と同じく, 湿度 $60 \%$, 気流 $0.4 \mathrm{~m} /$ $\sec$ との回答だった。

647 : 衣内湿度測定を水蒸気の量による熱伝導率の変 化を利用して同時に多点測定のできる装置を作成して行 つた新しい試みである。従来，衣内湿度の測定には各種 の湿度計が用いられているが, 種々の問題点があり, 本 法が実用化されることを望みたいとの奥田（広島大）の 発言があった。追加資料あり。

648：ハイソックス着用の体温調節に及ほす影幚を知 るための基䃈実験で土原（公衆衛生院）からソックスの 材賢により産熱量に有意差が出ているが，深部温は湘定 したかとの質問に，舌下温を測定したが，ほとんど変動 はなかったとの回答があり，また足部に接する部位の条 件について討議がされた。

649 652（483～486頁）座長 緒方 昭 (福井医大) 649 : 衣料による皮间障害の発生状況を主婦対象の面 接調查によって明らかにし, 昭和 46 年 (13年前) 時の調 查結果と比較して障害発生率が半隇したこと，およびそ の他の知見について報告された。本研究は, 長期間の観 察から得られる貴重なものて，公采衛生学の分野におけ る研究は、こうあらねばならぬと考える。

650 : 衣料加工処理剂 6 種について, 皮店障害発生の 有無を知るために，接触皮间炎患者40名を対象に，苛酷 と思われる48時間閉鎖貼布パッチテストの結果, 対象処 理刜すへてに陽性反応がみられたとの報告である。今 後，研究がどのように展開されるか興味深い。

651 ：今日，垵たきり生活者（老人）の住環境に関する 研究は, 衛生学者の担うべき重要課題である。実態調查 と被験者実験により得られた基䂣的知見から, 業者依存 型から業者指裂型へと，研究を哞展させて頂きたい。

652：東北地方の季節別温熱環境に適した標準的着衣 のあり方を設定することを最終目的として, 今回は, 四 季における着衣状況と温冷感覚について, その実態を調 查した結果が報告された。次回には, 温冷感覚と着衣状 況との関係を検討し, 性・年齢・作業状況等の別に, 標 準着衣モデルが発表されるものと期待する。

701 704（263 266頁）座長 常倰鞾三（宮崎医大） 701 : モルモットに500 ppmの $\mathrm{SO}_{2} 8$ 回間欠暴蕗を行 い body plethysmograph 用い R.F., T.V., sGaw の 測定を行い, 各測定值の時系列解析を行い暴露開始後す
へての指標は変化するが，40分後には非暴露時のレベル に回復する興味ある結果が示されたが，この機序につい ては今後の研究が期待される。

702，703：ラットにペントバルビタール投与し，気管 切開を行い，ボディプレチスモ内に保定したチューブに より，上部気道、下部気道にそれぞれ直接, 生食, 水, $0.01 ， 0.1 ， 1 \mathrm{~mol} / 1-\mathrm{H}_{2} \mathrm{SO}$ をそれぞれ $1 \mathrm{~m} l$ の air と共 に吸入し，上部気道下部気道の変化（Fin, Fex, Tin, Tex, Vin, Vex）を検討し，上部気道では刺激により 吸気及び呼気時間が長くなっているが，下部気道は注入 後 V は減少, Fin/Tin が減少, 一回の㭔吸時間の短縮 により生じるなど上部気道と下部気道の反応が異なるこ とが, 報告されだ。

$704:$ 三重県四日市の楠町で1972，1977，1980，1983 年に 5 才未満, 40 才以上の対象者について呼吸器症状の 調查を行い，慢性気管支炎有症率，5才未満の持続性せ き・たん有症率，5才未満の喘息有症率はいずれも二酸 化硫黄濃度の減少とともに減少し1980年以降では対象地 区との間に差がなくなったことを報告された。

\section{5～708（267～270頁） 座苌 安達元明（千葉大）}

705 : 小児期の呼吸器疾患既往（10歳時調查）, 特に気 管支喘息，喘息性気管支炎のあるものは 4 年後の呼吸機 能検㚗で，無症状のものよりも低值であることを示し た。家庭内喫煙・暖房器の種類・大気污染との関連につ き質疑があり，それらの因子との交絡はみられないとし た。

706 ：主要幹線沿道の小学校在校生を対象とした調查 であり，住居の $\mathrm{R} 43$ からの距離が300 $\mathrm{m}$ 以内のものは、 それ以上の地区に居住するものよりも呼吸器症状が多い ことを示した。拡散により沿道污染は $100 \mathrm{~m}$ を超えない ため， $300 \mathrm{~m}$ までのものが高率であることを如何に解积 するかについては，学童の生活行動範囲も考慮すへきで あろうとした。また学校の位置（沿道50 m) の影留も無 視出来ないとの指摘もあった。

707 : 居住環境 (住宅の種類, 宽室の床, ペット) と学 童の IgE，ダニ IgE との関連性を検討したものである。 $\mathrm{IgE} 300 \mathrm{U} / \mathrm{m} l$ 以上, RAST 法 Grade 2 以上のものは, 気密の高い住居に多く，また寝室のジュータン使用，ペ ット飼育（特に小鳥）とも関連があるとした。タ二抗原 の特異性についての指摘があった。

708 ：低濃度污染が人体及び植物生育に及ぼす影謷に ついて検討した。10年以上にわたる研究の一部であり， 杉の年輪指数と学童の呼吸器症状の悪化の相関が高いこ 
とを示した。慢性気管支炎調査用に作成された BMRC 躓問票を小児の調査に用いることの是非についての指摘 があった。

709～712（271～274頁）座長 森山忠亚（奈良医大） $709 ， 710 ， 711 ： 3$ 題は桜岛火山灰による健康㷧望に ついての興味ある発表がなされた。

西井はその火山灰の粒子と化学組成について分析して いる。これによれば微粒子, 小粒子での主成分は $\mathrm{Al}$ (70 \%) : Si (15\%) であるのに対し平均4 $\mu$ の中粒子では Si (50\%)：AI (40\%) で粒子の大きさによって化学組成が ことなることを指摘した。Si 含量が多いことは肺胞細 胞の線維化を招来するおそれもあり他の火山灰との比較 など質問がだされたが火山灭として特に Si が多いもの ではないとのことであった。

次いで矢野は火山灰による炎症起因性について培養細 盷系を用い，アラキドン酸の放出 C3 活性化, chemotaxis など恰討した結果いづれもネガティプであること を報告した。

しかし今後これらの手法によって人での補体価, 溶血 性など究明されることが期待される。

最後に横山は降下火山灰量によって 3 地区を設定し， ATS-DLDによる没学調查結果を報告した。降下火山 灰量の多い大隅半島の地区が他 2 地区に比し慢性呼吸器 症状の有症率が有意に高いことを示し注目された。調查 時期が 9 月であったことから季節的変動特に冬季空の開 閉などによる影望について質問がなされたが今後も続く 火山灰は個人レベルでのばくろの実態を把暒し，疫学調 査の継続の必要性のあることを強調された。

712 : 池田は仙台市都心部の降下煤塺測定により毎年 そのピークが冬季に集中し，スパイクタイヤによるもの てあるとし, 対象集団37,000の自賞症状調查を行い, 各 地区の大気性状と調查結果を比較し，仙台市が対象地区 に比し上気道自覚症状の有症状者率の高いことを報告し た。なお表 2 中の ppm は ppb と訂正。

スパイクタイヤによる降下煤筀による健康影算は仙台 だけのことではなく広く各地で調査されることが期待さ れている。

713〜716 (275 278頁) 座曼 百々栄徳（山口大） 713 ：揮発性化学物貝の光分解性のテスト手法につい て検討した発表て，抄録のような方法で 2 試験機関で行 つた検查でかなり良好な一致性を認めている。貿疑や追 加はなかった。なお 12 行目の $\mathrm{NO}_{2}$ は $\mathrm{N}_{2}$ に, 20,21行
目の〜エタンは〜エチレンに訂正された。

714 ：光化学反応による過換気は心因が直接的な原因 とされるという発表であるが，直接の引き金となる Factorは，局所刺激は単なる引き金か，心因も関与し ているかも知れないがそうクリアーカットにならないの ではないか，運動が換気の増大・口呼吸による局所刺潄 を增大するためではないかなどの反論があり議論がかみ 合わなかった。今後の検討をまちたい。

715 ：運送業従事者の排気がスと乫煙の影響について 検討した発表で以下の質問に対し，排気ガスと喫堙とで は喫煙の影響が大きい，車の大きさ・燃料の種類・走行 距離・経験年数・タンニンの量などによる差については BMRCなので詳細は分らない, 図 1 は年齢については 補正していないと答えた。

716 : ディーゼル排気ガスのラットなどの肺腫場発生 に及ほす影製についての発表で，発癌物質との併用では 粉じん沈着による組織変化が影敕するのかとの質問には 確定ではないがそのように推定される，長期間実験で他 の死因による死亡や感染症との関係は，との質問にはあ まりそのような死亡はないと答えた。この発表は中間発 表であり今後の研究の成果を期待したい。

717 721（279 283頁）座長 中島求知（香川医大） 717 ：本法による液ク口試料は，従来の超音波抽出試 料に比へて狭雑物が少ないため，カラム充虽剤の損耗が 少なく，多数検体のルーチン分析には経費的に有利であ る。さらに分析所要時間の短縮化が望まれる。

718 ：肺㢞など呼吸器と空気中に存在する発癌物質の 量・反応関係を明らかにするためには，释気道投与法に よる必要がある。本法は比較的简単な吸入による発癌性 スクリーニング法の一つとして有用であり，さらに同一 物質について種々な粒径サイスによる検討が望ましい。 719 ：今後，採集地点を増やして，発生源との関係を 解析できるモニタリングシステムの確立に寄与するよう 研究の発展が期待される。

720 : 吸入 $\mathrm{O}_{3}$ が $\mathrm{O}_{3}$ のままて血流に入ってリンパ球に 作用するとは考六難い。肺胞壁構成物質の $\mathrm{O}_{3}$ による酸 化生成物貿の血管内注入実験などを組み入れる必要があ ると思われる。

721 ：単に相関係数のみから, 文献の恣意的引用によ って，因果関係があるかの発表は，内容が市民の生活に 深く関わることがらであるだけに，学問的に慎重であっ て欲しい。 
722〜725（284〜287頁）座最 石川声文（千葉大）

722 ：原爆被爆者について 10 年間の固定集団のうち, 女性の非喫煙者を対象として, 受動喫煙と肺ガンとの関 連を観察したものである。その結果喫煙者の喫煙習慣は 変わらないものと推定し, 被爆の影整も考虑して解析し たが, 受動喫煙の場合煙の睫露状態の推定の困難さはあ るが,肺ガン症例にお゙いて受動喫煙により肪ガンのリス クが増加することを観察した。

723 ：喫煙と尿の変異原性との関係を Ames 法により 観察したものである。個体差があり，非乫煙時のパター ンあるいは試験的に実施されたビタミンCとの関連も明 確てなく，また食事内容など契煙以外の要因の関与も考 えられ，今後の検討が期待された。

724 : 尿中ハイドロオキシプロリンとクレアチニン比 （HOP 比）が能動, 受動哭煙によって增加する機序を解 明する目的で行われた実験である。受動喫煙については ある程度の疑問は残るけれども，能動喫煙における尿中 HOP 比の増加は, 血清 $\alpha_{1}$-Antitrypsin 濃度の増加々 trypsin inhibitary capacity の低下との関連が関与して いるものとされた。

725 : コレステロール投与による高脂血症と喫煙が肝 と肺の薬物代謝醉䒺に及注す影響を検討したものであ る。その結果高脂血症と喫煙あるいは両者併用とで筫的 に異なった効果が観察されたが，薬物代謝酸素について は12週後の観察であるので，経時的に観察されれば，よ り効果的な結果が得られたのではないかと推察された。

\section{6〜730（288～292頁）座長 春日 斉（東海大）}

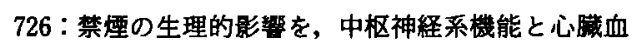
管系機能の 2 面から考察し, 常習喫煙者の中枢神経系機 能に煙中COよりも，煙中ニコチンが強く介在している と結論している。また，実験第1日目はニコチン添加シ ガレットの粱煙，2日目は無ニコチンシガレット䒜煙， 3 日目は非点火モギ喫喓 (Sham 乫煙)を行っている。

727 : 牛乳気道感作動物にシガレット煙を吸入させ, 心電図 $\mathrm{R}-\mathrm{R}$ 間隔の㚆動の大小から自律神経の機能状態 を評価した。すなわち, 感作群とコントロールの非感作 群では自律神経機能は異なり, 感作群のVTがより強 く, 喫煙によりもたらされる頻脈性変化も強いと結論し ている。

$728 ： カ ゙ ラ ス$ 絾維フィルターで粒子成分を捕集した後 のシガレット煙に妊娠ラットを㮔露させ, その胎仔の状 態からシガレット煙中気相成分の胎仔発育に与える影翠 を評価した。
シガレット煙による胎仔発育抑制には気相のみならず 粒子相も関与し，気相中には CO 以外の抑制物質例えば シアン等があることが示唆されたとしている。

729 ：ヒ卜の呼吸中炭化水素 (エタン, エチレン)を測 定することにより，呰煙が人体における脂質過酸化に及 ぽす影響を検討した。

起床後禁煙状態の契煙者の呼気中エタン・レベルは非 喫煙者より約 3 倍高く，1本の喫煙により肺中に取りこ まれるエタンは 4 時間, 呼気中エタン量に影響したとし ている。その他乫煙習慣によって取りこまれる煙が人体 内の脂質過酸化を六進するとし，フリーラジカルやオキ シダントがシガレット煙にあり，Santosらの報告と共 にこの成縝を支持している。

730 ：職場における禁煙行動を調查し，それに夙与す る要因につき特に䝟煙歴を取り上げた。

梨煙者の禁煙は多く短期間で中断し，喫煙年数が長い ほどその傾向が大きい。禁煙時の離脱症状の程度は喫煙 年数，本数と関連し，長期の大量喫煙により Tabacco Dependence の危険性が増加する可能性を示唆してい る。以上に対し，Ex-Smocer との比較も必要とすると の追加コメントがあった。

\section{734（487〜 490頁）座長 村上忍三（信州大）}

731 : 佐賀医大·地域保健科学教室は, 高度の測定技術 に基づき, 衛生学領域に大いなる頁献を残されている が，平井は GC/MS を用いて地下水中のトリクロロエ チレン測定に，新分析法を確立した。検出限界 $1 \mathrm{ppb}$, 変動係数 $2 \%$ と再現性もよく，優れた分析法といえよ う。鏡田 (京都衛公研) は, ECD ガスクロなど他の方法 との比較を論じ, 平野 (千菜大) は, 地下水の動きと探 取法, 及び地上の污染の可能性を質問した。

732 : 鎌田 (京都衛公研) は, ごみ焼却残渣中の PCDD 含有量を GC/MS 分析により測定し, 乍の種類, 焼却 炉，燃焼温度などによりかなりの差のあることを認め た。池田（東北大）は燃焼温度（連続800-900 $\mathrm{C}$, 限界 温度1400-1600 $\mathrm{C}$ と答）と異性体分離法（フロシリルカ ラムクロマトグラフィー) とを䁈問し, 異性体により毒 性に差があることを示された。

733 ：池田 (東北大) は, 環境中の化学物貿の評価法に ついて数理統計理論を駆使して，価値ある提言をされ た。 5 項目の説明変数のなかでも生産量とオクタノー ル/水分配係数とが最も貢献できるとした。平井は検出 できる大気圈データなとにいつて質問した。

734 ：坂井 (北海道大) は，河川底質土の 6 重金属分布 
を粒径別に原子吸光分析法で測定し，季節変動，流水量 との関係のあることとともに, 污染指標としても有意義 であることを示唆した。島（保健衛生大）は粒径分画が 污染源の種類, 程度, 距離, 時間などによって,どのよ うな影篹を受けるかと問い, 関連性ありと答えた。鎌田 (京都衛公研) は, 分画 $\mathrm{A}$ と $\mathrm{D}$ との淟度比が下水処理七 ンターの上下により压があるかと問い, しかりと答え た。一般に家庭排水ては微細なものが多いという。

以上 4 題とも確実な分析法を基喏として, 衛生学の発 展に則した優れた研究であり，今後が期待される。

735〜739（491～495頁）座長 秋山 高（産業医大） 735 :シリーズ第 6 報である。一般生物学的污染指標 は広く実用されておるが，演者の指向する細菌醉素活性 と水質污濁評価の研究の発展を望みたい。

736 : 水瑟境生物体内中の微量元素分布と污罚影響に 関する研究である。元素瀑度順位を実験結果により, 羅 列していたが客観的考察を欠いていた。

737,739 : 硫黄廃鉱下流域の酸素河川水の水道水に対 する影響，実験動物（ラット）に対する生体影響につい ての報告である。

738 : 河川水飲用群の血清中無機硫酸塩の測定值の標 準偏差 (S.D.)が大きいことは何らかの生体影響を示すも のてはないか (山口大・大崎) との発言があった。演者 らの研究で一応の結論を得られた印象を受けた。

740 743(496〜499頁) 座長 岡田 晃（金沢大）

740 : 保線労働におけるマルチタイタンパー運転に伴 う全身掁動にあたえる影辢，労缏負担要因意識を質問紙 票によって謂査したものである。全年齢てみるとマルチ タイタンパーの職種で自賞症状の頻度分布の有意に高い 項目が多いのに，25〜34才代でみるとそれがなくなって いることからその職種に基づく結果というより対象者の 年齡構成に基づく可能性があると考えられるという座長 の指摘に対して高齢者で訴えが高いようであることが回 答された。

振動障害の診断項目を回帰係数により検討した演題 741 は, 各検㚗項目より時系列に 2 項目ずつとり出し, 前の項目 $\mathrm{X}$ と後の項目 $\mathrm{Y}$ を白指有無群について共分散 分析によって比較したものである。

742 ：自覚症状を有しないチェンソー作業者 6 名を対 象に常温下における変動を㓋察し, 皮成温と爪圧迫テス トの間に負相関を認め, 皮间温と振動感觉闘值の間には 一定の関保は認められないことが報告された。大崎（山
口大）から平均值て結論するよりも標準偏差の経過が重 要であること，また鈴木（福島医大）から測定装置の装 着, 実施の経過と観察結果とのかかわりについての指摘 があった。

堀川（高知医大）によって発表された演題743では, 高 知県下に扔けるずい道建設出稼者を対象に振動障害, 歴 肺の認定患者を職種にわけて検討し, その分布から出稼 ぎ供給地域を明らかにし, 問題点が抽出された。坂本 (三重大)から高知県以外で認定された思者も含めて観察 する必要があるという意見が述べられた。

744 746 (500 502頁) 座長 坂本 弘 (三重大)

$744: 60 \mathrm{dBA}$ 以下ては暗騒音の影響が無視し得るこ とから，防音ボックスを要しないので携帯用化の有用性 が強調された。暗騷音影響の検討に用いられた white noiseの周波数帯域を明らかにし, 従来からのマスキン グ理論との整合を検討する必要が討論された。

745 : 文献4)の成績との一致は $2 \mathrm{KHz}$ 以上で適用て きることが追加された。また, 内耳への dose の評価に あたって，人耳の指向性を前提として，いかなるマイク ロホンの使用がベターかについて論じられた。

746 ：うるささ・大きさなどの日本語と英語表現との対 応について, また心理的応答の個人差について論議され た。

747 750（503〜506頁） 座長 斎藤和雄（北海道大） 747 : 脳内カテコールアミン量を Fleming 法と諸治法 を用いて測定し，両測定法のノルアドレナリン（NA）， ドーパミン (DA)，セロトニン (5-HT) などに対する回 収率を比較したところ，測定値の分散扔よび回収率にお いて諸治法が優れていること，さらに，30分 $100 \mathrm{~dB}$ (C) の広带域音の連続暴露により, 視床下部の DA 量が有 意に低下することが認められた。これに対してDA低 下の理由, 腷内エピネフリン量の変化はどうなどとの質 問がなされた。

748 : ラット脳内 $\mathrm{MAO}$ 活性の季節変動と週齢との関 係を検討した報告であり, 脳内 $\mathrm{MAO}$ 活性值は大脳お よび脳幹で 8 週齢および12週齢で有意な季節変動, すな わち冬低く, 夏高い值を示し, この変化は無空調群にお いてより大きいことを示した。これに対して変動差は自 然現象，とくに気象条件によっていると解秎するのか, 空調の温度, 湿度などに関する設定条件についての質問 がなされた。

$749: \gamma$ 分布に似たアラン分布モデルを応用して, 道 
路騒音の $\mathrm{L}_{50}$ を求めるシミュレーション研究であり, 無 限長および有限長道路の場合の例について $\mathrm{L}_{50}$ を求める 式を夫々示し，実際の数值を道路から2，8，32，128, $512 \mathrm{~m}$ て求め当てはめた。得られた式とモデルとの羑に ついて検討した。これに対し，本法の意味と意義につい て質問があった。

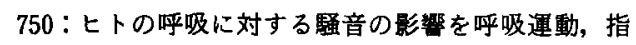
尖眽波, 皮成温を湘定しとくに呼吸曲線の解析結果を 示したもので, $105 \mathrm{~dB}(\mathrm{~A})$ ピンクノイズ暴露で総換気量 が抑制される結果が得られたが, 詳細な検討は今後行わ れるとのことであった。

\section{754 (507 510頁) 座長 山本刚夫（京都大）}

751 : ラウドネス等との関係, もう少し早い変化の把 握の可能性等に関する質問があり, 今後, 検討したいと の回答があった。

752 : 検出力について検討しておく必要があるとの注 意があった。なお, 本講演の表題に関する疑義も提出さ れた。

753 : エーテル麻酔の影響, 対数正規分布としての取 り报いに関する質問があり，前者については，2 分以内 の穿刺であり, 無視しうること, 後者については, 分布 の同定はしていないが，㭘定は対数変換の後行ったとの 回答があった。

754 ：臨界帯域を検討するには，スペクトルレペルー 定のままで，带域幅を搪大したほうが良いのではないか とのコメントがあった。

\section{803（293～295頁）座長 藤木罪士（筑波大）}

801：魚介中メチル水銀の分析操作を効率よく行うた めに, ジチソン抽出一ガスクロマト法による分析法を検 討し, 従来の分析法で $\mathrm{T}-\mathrm{Hg}$ に対する $\mathrm{Me}-\mathrm{Hg}$ の割合が $60 \%$ ものが $100 \%$ 近くとなるような結果が報告された。 これに対し，魚介中 $\mathrm{Hg}$ のほとんどが $\mathrm{Me}-\mathrm{Hg}$ であると すれば，無機水銀の形で魚介中に忣収された $\mathrm{Hg}$ および 魚介中で無機化した $\mathrm{Me}-\mathrm{Hg}$ に由来する $\mathrm{Hg}$ はどうなる のか説明できなくなること, 約15年前すでにジチソン抽 出一ガスクロマト法による分析法が検討された時はよく ない結果しか得られていなかったことからこの分析法に 疑問が持たれるなどの発言があり，さらに検討願うと同 時に，追試を受けて改めて討議することを座長として提 案した。

$802:{ }^{153} \mathrm{Ga}$ を放射線源とする蛍光 X 線を利用して脳 中 $\mathrm{Hg}$ おび生体中 Cdを in vivo で測定するための装
置を開発し，Hgでは0.1ミリモルまで測定できること が報告された。これに対し，現在の人体，とくに脳中 $\mathrm{Hg}$ は0.05 ppm 程度であることから，その実用性に疑 問を持つ発言があり,この装置の感度はさらに100倍程 度向上する旨回答があった。今後の改良進展を期待す る。

803 : 人体臟器中の $\mathrm{Hg}$ と毛答および血液中の $\mathrm{Hg}$ 濃 度とを比較したところ, 毛髪中 $\mathrm{T}-\mathrm{Hg}$ と蔵器中 $\mathrm{T}-\mathrm{Hg}$ の間により相関がみられ, 臟器中 T.Hg を測定する代

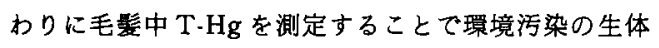
におよ浪す影響を検討できることが報告された。バイオ ジカルモニタリング手法として使用が期待される。

804〜807（296〜299頁）座長 滝澤行雄（秋田大）

804 : 渡辺ら（筑波大）によると，メチル水銀のマウス 側脳室内投与水銀の臟器内分布と排泄のパターンは他投 与法のそれと大差なく，脳内への蓄積は僅少であるか， 投与後急に低下, いったん増加傾向を示したのち, 低下 している。この他臟器と相反する結果は, 水銀が脳と他 臓器の間を循環しながら排泄されている可能性を示唆し た。

なお，表示の Mercury content concentration に 訂正した。

805 : 平山ら (水俣病研究センター) はメチル水銀投与 後のマウス尿中排泄水銀量に著明な性差（雄>雌）をを認 め, 性ホルモンの腎機能への関与を考究した。これに対 し, 尿中水銀の化学型やマウスに系統差が大きい問題, 性ホルモンの周期性への考虑などについて活発な討議が なされた。

806 : 三尾ら (神户大) は, ハイドロダイサルファイド のチオシステアミン (TC)によるメチル水銀の排出を個 体レベルで検討するため，マウスに体重変化のないメチ ル水銀莀度が各藏器に詝留した後の TC投与効果につい て詳細に報告した。その結果, 肝と腎で総水銀とメチル 水銀の速やかな減衰が認められた。

807 : 本郷ら（東京大）は, 一般人における赤血球中水 銀と赤血球・血漿・尿セレンの関係を検討し, セレンの 栄黄状態は魚の摄取量と密接な関係があると推論した。

講演集の要旨全面訂正があり, 配付された資料では赤 血球セレンと血漿セレンの性差がかわり，女>男とな り, 特に赤血球セレンに $p<0.001$ 有意差が認められ ている。魚肉中のセレンは水銀と必ずしも相関はない が, セレンの水銀に対する拮抗作用が注目されているだ けに, 今後の研究が期待される。 
808〜811（300～303頁）座畏 軨木链美（東京大） 808：雄ラットにメチル水銀を投与した時の血中各種

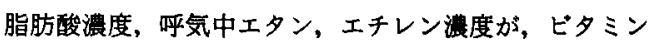
E 添加によりどのように変化するかを追いかけた研究て ある。メチル水銀による上述の各種パラメータの変化に 対するビタミン Eの影算は必須脂肪酸と呼気中エチレ ンについて認められ，脂贒過酸化の抑制が推定された。 809 ：踓ラットを用い,メチル水銀と亜セレン酸を等 モル，同時または $1 ， 2$ 時間の間隔 (メチル水銀を先に) を置いて皮下注射した時の呼気中セレンの排泄をみると 同時投与時にもっとも大で，亜セレン酸単独投与時にも っとも小であった。さらに亜セレン酸による体重隇少は メチル水銀添加（それ自体では体重隇少を起こさない）

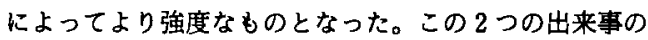
間の関係について推論が加えられた。

810 ：雄ラットにメチル水銀（铜料中湿度 $20 \mu \mathrm{g} \mathrm{Hg} / \mathrm{g}$ ) を与えた時の visual evoked response (VER) の変化を 見た研究。脳水銀湌度 $1 \mu \mathrm{g} / \mathrm{g}$ をこえた所て、VERの 潜時の延長が認められた。この変化がメチル水銀中赤の 初期症状としてどのような位置を占めるか興味がある。

811 ：雄ラットを用い，メチル水銀の1回皮下注射時 に各種の内分泌機能がどのように変動するかを広範囲に 検討した研究である。その結果の中て，どの実験でも安 定した変化を示すものとして下垂体一甲状腺系が特に注 目され，T、の隇少，TSH の上昇は量・反応関係を示し ていた。この他に, 下垂体一性腺系, 下垂体一副腎系な どにも変化があり, 今後の研究の必要性を示唆した。

\section{815（304～307頁）座長 住野公昭（神戸大）}

812 : 水俣地区居住者の剖検臓器中総水銀, メチル水 銀の分析報告。この10年間, 肝堅, 大脳, 小腷の水銀量 は殆ど変化がないと報告された。認定・非認定患者の判 別分析は誤判別率が高く，判別が難しいと結論された。

813 : 正常出産時に母体血, 脆帯血, 胎盤を採取し, 総水銀，無機水銀，鉛，カドミウムを測定。水銀仙胿带 血が母体血より高く, 鉛とカドミウムは逆であった。こ の種の調查は従来とも多く行われているのて, 今回の值 は高くはないか, 初産と経産の差, 羊膜の分析值, $\mathrm{Pb}$ と Cdの化学形態はという各質問に対し，比較していな い, 区別していない, 分析していない，いまだ検討して

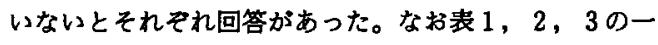
部の値に訂正があった。

814 ：胎児性水俣病発生時 (昭27〜39年) 水俣市の出生 性比を調查し, 対照と比較模討した。特徴的なのはこの
間性比が低いことで，これを亳付ける料はないが，性 決定時の影膤よりは，胎児期のメチル水銀の抵抗性の差 かもしれないとした。しかしこの間早産・死産が多かっ たことを証明する资料がなく，今後この調查の意義も含 めてききとり調查などの必要性が東田より強調された。

815 : 水俣水銀污染地区, 能本県, 鹿児島県の昭和 44〜 57年の料から生命表を作成し, 平均余命, 特定死 因を完全あるいは一部除去したときの余命ののびを算定 した。污染地区と他地区とで余命に有意差がないが，特 定死因として事故を除去した余命ののびは地域特性がみ られた。污染地区住民は11万人と大きい集団なので, 差 が検出できなかった可能性があるとした。

\section{6〜819（308～311頁） 座長 山口誠哉（筑波大）}

816 : 演者の云わんとするところは, 高血圧自然発症 ラット (SHR) のメチル水銀投与実験において見られた 死亡パターンから, 高血圧症はメチル水銀中毒の発症に 及ほす修飾因子の一つになり得るということであった が，それは単に動物の種差を見たのみではないのか,人 間においては高血圧とメチル水銀中毒との関係は確認さ れていない，等の意見が出され，更に傎重な実験とその 評価が要求されると結論づけられた。

817：好塩基点赤血球と水銀製剤の関係についての研 究はあまり見られないか，塩化第二水銀投与例において はBSE 顆粒の大きさの分類では微少かつ数の少ない型 が多く, 鉛の場合との差異が注目された。

818 ：B 群レンサ球菌の第二塩化水銀に対する耐性に 関する研究であり, 耐性を支配する mercuric reductase 活性を検討したものである。B群レンサ球菌 についてはプラスミドあるいはトランポソンは分離されれ ていない。

819：歯科用アマルガム充虽は日常おこなわれている 治療法であるが，水銀アマルガムを使用するが故に溶 出, 吸収の程度の評価は重要である。しかしこの研究の 結果によれば，食品よりの摄取量の約11分の 1 ほどであ った。

$820 \sim 822$ (312 314頁) 座長 久保田菁太郎 (国立公 害研)

820: Metallothioneinの測定に関するものてあり, 多量の検体を処理する目的で開発されたものて，従来の Cd 飽和やへモリゼート処理をしなくても，1 分間加熱 て簡便に測定しうることが判明した。分析手法について 野見山（自治医大），土井（奈良医大）加結合様式，加 
熱時間，温度に関する質疑が行われた。三種（国立公害 研)より Table の $\mu \mathrm{M} / \mathrm{g}$ は $\mu \mathrm{M} / \mathrm{g} \times 10^{-3}$ の誤の指摘があ $\eta$ ，遠山（国立公害研）は Cd-Th, Cu-Th, Zn-Thの 3 分画にわけているが，それぞれの金属峘度の最も高いも のに Thをつけることが国際的に定義づけられていると の追加発言があった。（Table の Cd-treated Liverの B 法の項て Cd-T 7.4, Cu-T 82.5, Total MT 89.9 と訂正) $821 ： 820$ の方法を食用貝に応用したものである。バイ

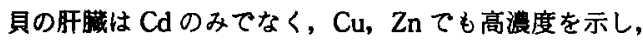
MT 漂度もひときわ高かった。 3 種の金属の肝/筋肉の 簒度比においてもバイ貝のみ特異的な傾向を示し (13000), 肝 Cd 瀑度の比較的高いアカガイ, サザエ, トコブシのCdの肝/筋肉比は他の 5 種にくらへて高い 值 (19〜177) を示した。分析法としての加熱法と Cd 飽 和法との間には特に差はなかった。（表 $32 \mathrm{Zn}-\mathrm{T} \mu \mathrm{M} / \mathrm{g}$ の行の 3 列 $16 \rightarrow 23$ と訂正)

$822: \operatorname{Cd} 100 \mu \mathrm{g} /$ 匹/日100回経口投与し，20\%蛋白 食， $5 \%$ 蛋白食を与えた時の肝，祭の蓄積量について性

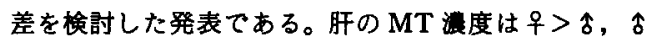
では低蛋白食の方が高値を示し，竍では体重あたりの $\mathrm{Cd}$ 負荷量に依存しており，肝の Cd-T, $\mathrm{Cu}-\mathrm{T}$ 共に早> 今であり，低蛋白食の方が高蛋白食よりも高い值を示し た。一方留では Cd 湌度で性差がみられるにも抱らず， MT, Cd-T, Zn-T, Cu-T は性差及び低蛋白食による 明らかな差はみとめられなかった。（表 1， $2 \mu \mathrm{M} / \mathrm{g}$ $\rightarrow \mathrm{nM} / \mathrm{g}$ と訂正)

823 826 (315 318頁) 座長 福山䜪三 (旭川医大) 823：ラットにCd を投与し，肝，粗および尿中のメ タロチオネン (MT) および Cd， $\mathrm{Zn}, \mathrm{Cu}$ の檂度の推移 をみた実験である。肝，腎のCdレベルはCd 投与後上 昇し 6 週以後は頭打ちとなり, MTは Cd と同様の変化 を示し，尿ではまず，MT が出現し，4週後からCdが 出現するという。この実験で尿中 MT の増加は尿細管 機能低下以前に現れることを示した。

824 ：ラットから作った Cdメタロチオネンをラット に投与し，どれ位の量でどのような堅障害がおこるかを 尿中の ALP, $\gamma$-GTP, LDH, NAG, グルコース, 尿 蛋白, 呼気中の炭化水素を指標として調べた実験であ る。尿中の ALP, $\gamma$-GTP の増加は近位尿紐管のブラシ ュボーダーの障害を示し，尿中 LDH，NAGの増加は 堅の細胞の変性によると考えている。この演題に対し， 安藤（鹿児島大）から呼気中のプロパンの変化と脂肪酸 の関与について質問があったが, 演者は現在, 検討中て
あると答えた。

825：Cdメタロチオネン投与のラットの尿中のCd, $\mathrm{Cu}, \mathrm{Zn}$ の壊度の経時変化を調べた実験である。多量に 投与した群で Cdが投与直後に多く排泄された。また $\mathrm{Cu}, \mathrm{Zn}$ も投与後に多く排泄されるが，これは堅障害に より㹂より逸脱したものと考えている。また，蔵器内の $\mathrm{Cd}$ 蓄樌量は肝ては投与量と比例して多く蓄積している が盈では150 $\mu \mathrm{g} / \mathrm{kg}$ b.w.が限界でありそれ以上ではむ しろ低くなっていることを認めた。この演題に対し，野 見山（自治医大）から臨界濃度についてのコメントがあ った。

826：水銀または Cdの暴露により尿中にメタロチ才 ネンが出てくるが, その機構の解明のために行った実験 である。水銀をラットに投与すると腎に Hg が蓄稘し， 腎でメタロチオネンが作られ，尿中に $\mathrm{Hg}$ およびメタロ チオネンがでてくる。この際，近位尿細管のブラシュボ ーダーが障害され尿中の ALP およひ $\gamma \cdot$ GTP が増加す る。Cdを投与すると肝でメタロチオネンが作られ，堅 においてもメタロチオネンが増加し，その結果，尿中に もメタロチオネンが排出されるという。

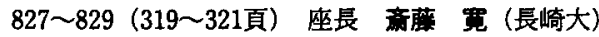
827 : 望月らはラットに $2 \sim 4 \mathrm{mg} / \mathrm{kg}$ 体重の酢酸カド ミウムを腹腔内投与すると補体価 ( $\mathrm{CH} 50, \mathrm{C}_{3}$ 量) の著 明な低下をみたと述へた。演者の投与量ではラット腹䑤 にかなり激しい炎症をきたすと考えられるが，その影響 をどう考えるかとの疑問が会場よりなされた。

828：赤堀らはカドミウム長期投与 (サル実験) は加龄 にともなう血圧上昇を抑制すること，またこれは脂筫代 謝が正常に保たれることに関連すると述べた。血圧調節 は内分泌，腎ほかの機楎が複雑に関係しているはずだ が,これらにまったく言及せず脂質代謝としてよいの か，また，報告では血漿コレステロールとトリグリセラ イドの時間的推移しか示されていないがこのことから 脂實代謝正常といってよいのか，などの疑問が会場から 出された。協同研究者の野見山はわれわれはきわめて重 大な仕事をした。この問題に関心をもつ研究者は追試を 行うべきであると述べた。

829 ：演者が海外出張したため紙上発表となった。

830 834（511 516頁）座長 能川浩二（金沢医大） 830 : 量一反応曲線より求められる期待発生率と予測 発生率との差についての数学的検討である。発表者のい う予測発生率, 及び期待発生率について, 実際的事例が 
どう適応するかが今後の課題であろう。

831 ：カドミウム污染地住民の 10 年後の尿所見の変化 を検討したことについて，尿所見增加の原因，摄取 $\mathrm{Cd}$ 量の変化，秋田，長崎の污染地の実態についての討論が あった。個人についての追跡も必要と思われた。

832 : 尿中アミノ酸排泄について，イタイイタイ病患 者, 慢性留不全患者, 対照者のアミノ酸クリアランスを 比較し，排泄機序の差について検討をした報告である。 特に討論はなかった。

833：カドミウム污染地住民の尿中にビタミン D 結合 蛋白が検出され，これは腎障害の程度と比例していると いう報告である。V.D 負荷時の尿中排泄について，及 ひ，系球体障害時の尿中排泄についての筫問があり，骨 変化との関連を含めて，今後検討するという答えがあっ た。

834 ：講演集ては尿中 $\beta_{2}-\mathrm{MG}$ がわずかに上昇した程度 でもCd作業者では，腎機能に関連した指標が軽度異常 を示しているとした内容であったが，追加资料におい て，年齢との関係を考虚すると，ほとんどの羊はなくな ろとして，結論の訂正があった。対照群とCd 污染群の 血清尿酸值が有意差のあることについて，かなり論議が あった。

835 838（516～519頁）座長 桜井治彦（鹿応大） 835 ：尿細管障害の指標として尿中 $\alpha_{1}-\mathrm{MG} と \beta_{2}-\mathrm{MG}$ を比較し， $\mathrm{pH}$ にるる安定性の点て $\alpha_{1}-\mathrm{MG}$ が優れてい ると述へた報告であるが， $\beta_{2}$-MG の正常域が低く，軽 度異常による変動が大きいので $\beta_{2}$-MG の方が䔬常の検 出力が良いという意見があった。又酸性尿による $\beta_{2}$. MG の活性低下は, 採尿直後にバッファー入りのバイア 儿尿を移し保存すれば事実上防止できるという斎藤ら （長崎医大）の追加があった。

836 : 各種の必須元素の尿中排泄が病患者で著しく 変動していることを示す成績である。特に鉄排泄の著明 な增加は, 鉄剂投与の影霎も否定できるので, 興味ある 知見と考えられた。亿病㭧者の重症度に入院，外来で差 があるかどうか質問があったが，差はないとのことであ つた。又，亿病患者の腎機能の現況についても筫問があ り,いずれも尿細管機能はイ病の典型例といえるとのこ とであった。

837：腎尿細管刷子緑膜に局在するトレハラーゼが Cd 急性中毒により激隇することを証明した実験てある。局 在性がどの程度のものか, 慢性中毒てはどの样な変化が 起こるかなどの質問があり，局在性は極めて高く，人て
は腸と堅尿細管に限定していること，慢性中毒では、1 病患者で尿トレハラーぜの增加が認められることが述べ られた。䝁光抗体法による証明ではトレハラーぜを用い る Positve Control 使用したかどうか質問があり，使 用したとの答えであった。

838：Cd 中毒家兔の腎尿細管刷子緑膜でソチーム活 性が著明に増加することを示す報告であり，リソチーム の生理機能などいまだ不明であるがその解明にも寄与て きるのではないかとのことであった。Cd中毒に特異か どうかについては他の腎毒物で検討中であるが現在まて のところ, 水銀では増加せず，ある種の抗生物質では増 加するなど物質によって異なるようであると答えた。

839 841 (520 522頁) 座長 渡辺正男(富山医薬大) 839 : 近位尿細管機能検查の方法として尿酸クリアラ ンスを検討した。対象としてファンコニー症候群13例， 原発性痛風10例，カドミウム土壤污染地域の 5 藏以上の 住民220人，および対照群として健常人，慢性系球体捐 炎加なる61例について䤃美法により尿酸を測定した。 対照群の血清尿酸は従来の報告と変わりないが，ファン コニー症候群は低尿酸血を示した。単位ネフロン当たり の㽷酸クリアランス $(\mathrm{Cua} / \mathrm{Ccr})$ は, ファンコニー症候群 では高値を示し，カドミウム污染地域住民ては50歳以上 で著明な上昇をみせた。採尿，採血の方法で討論され た。

840 ：骨皮質中におけるビタミンに依存性 $\gamma$-カルボキ シグルタミン酸含有蛋白質オステオカルシンと Cd との 相互作用，およびその機能に対する Cd の影響を検討し た。仔牛およびラットのオステオカルシンに対するCd の親和性は解嚯定数から $\mathrm{Ca}$ 上り $10^{2}$ 倍高く，Ca と結抗 的結合を示す。またCd 添加により紫外部吸収差スペク トルに変動を示し高次構造の変化を示した。

さらにハイドロキシアパタイトへの親和性は $\mathrm{Cd}^{++}$存 在下の方が強かった。討論の結果, 骨中のオステオカル シンは仔牛て $100 \mathrm{nM} / \mathrm{mg}$ bone powder で加齢と共に增 加すると報告された。人では $10 \mathrm{mg} / \mathrm{m} l$ bloodであつ た。

$841 ： \mathrm{Cd}$ の血圧への影響を考兄，血管平渭筋に対する 影響と作用機序について㬰験的に検討した。ウサギ腎動 脈の摘出血管を用い, 収縮力はStrain gage tranceducer (Shinko-tsushin) て輪状筋方向の収縮を等尺性 に湘定した。その結果，高浱度 $(139.5 \mathrm{mM}) \mathrm{K}^{+}$と Nor adrenalin による血管収縮性は血管の培善により增強ざ れ,この増強は $\mathrm{Cd}(200 \mathrm{mM})$ に上り抑制きれた。 $\mathrm{Cd}$ 
よる抑制はNor adrenalinに対し dose response を示 し,これは Nor adrenalin receptor に対するCd の抑制 によると推定された。

842 845(523 526頁) 座長 野見山一生 (自治医大) $842 ： \mathrm{Ca}$ ，蛋白 V. D, ，E 欠乏がカドミウムによる骨 粗銐症，腓腹筋の石灰化を強化するという報告であっ た。マウスに半合成飼料を 2 年間投与した労力のいる実 倹であるが，固形飼料のV. $\mathrm{D}_{3}$ 測定を行うなど細心の注 意が払われていた。腓腹筋の変化は筋原性で，加龄によ る変化と考えられる。骨粗瑟症と腓腹筇の変化のいずれ が先に出現するかは動物によって異なるとのことであっ た。

$843: \mathrm{Ca}$ ，蛋白欠乏がカドミウムによる骨粗籍症を早 期に，また，より強度にしているというのが昨年の報告 であるが，組織学的に確認されたという報告であった。 Osteoid の特殊染色はしていないが，組織学的にも，ま た, Softex 写真でも骨軟化症は特に認められなかった ということであった。

844：多量のカドミウムが睪丸の出血，壊死を起こす ことが知られているが，拿丸内微量元素も大きく変動す る,また,この変動はセレンの同時投与によって抑制さ れるとの報告であった。討議は，846と関連が梁いので， 演題846発表後に一括して行われた。

845：大量のカドミウム投与によって雄に激しい奚丸 出血が起るが，妊集性は正常であるとの報告であった。 これまでにも，優生致死法による後世代への影撆につい ての研究でも何ら変化が無かったとされており，同じ結 果であった。今後は, 慢性曝蕗時の妊孕性についての検 討が必要であるように思われた。

849 851 (530 532頁) 座長 加須屋実(富山医薬大) 849 : 本多ら (金沢医大) は，腎皮質中の $\mathrm{Zn}$ と Cd のモ ル比が, 肝膈中 Cd 濃度約 $30 \mu \mathrm{g} / \mathrm{g}$ 湿重量で減少するこ とを示した。すなわち，腎皮質中の Cd の臨界溇度を肝 臓中の Cd量を尺度としてとらえようとしたものであ る。遠山 (国立公害研) から, 肝葴中 $\mathrm{Cd} の$ 臨界濃度, と いう表現についてコメントがあったが，Cdによる肝臓 のなんらかの障害をみているわけではないので適当な表 現とは思わないと演者は答えた。小泉（兵庫医大）から 加齢の影響（加齢によって腎荿皮質中 Cd 濃度が下がる こと）について筫問があったが，この研究では年齢要因 は分析していないのでなんとも言えないということであ った。
850 : 能川ら（金沢医大）は，罩境 Cd 暴蕗者の血清中 $1 \alpha_{1} 25(\mathrm{OH})_{2} \mathrm{D}$ を測定し，Cdにより腎障害が発生した 人では, それが減少し, さらにその減少はPTHの増加 を伴うことを明らかにした。腎障害によりVit.Dの活 性化障害がおこり，PTHの代謝障害ともあいまって骨 変化に結びつくことが推定されるが, Vit. Dアナログ などの測定も含め，より詳細な検討が必要であることが 議論された。

851 ：釣谷ら（金沢医大）は， Cd 污染地区住民て Cdに よる腎障害の認められる人について姉妹染色分体交換 (SCE)を調へ，その頻度には非污染地区の人と比べ差は なかったこと，また，染色体異常も特に多くなかったこ とを報告した。寺西（富山医薬大）から，Cd暴露者であ るイタイイタイ病患者で高率に染色体異常があるとされ ていること (Shiraishi et al.) との違いをどう考えるか, 血液中の Cd 量に違いは無いのか, などの質問があっ た。どちらもCd量は測定していない。方法上の大きな 堂いはない, とのことで今後さらに検討する必要が論じ られた。

901 903（322 324頁） 座長 荒記俊一（大分医大） $901:$ グラファイトチュープモリブデンコーティン グ，高温灰化，および検量線による読みとりを特徴とす るフレームレス原子吸光法による血中鉛の直接測定法を 報告した (口演, 平井)。測定の再現性（CV）は $5 \%$ と よく，実用性があることが強調された。

902：全国14都道府県の主に農業従事者の 1 日鉛摄取 量を䔖膳方式で剆定した。男子は平均 $34 \mu \mathrm{g} /$ 日，女子 は31 $\mu \mathrm{g} /$ 日と従来の報告值より低く，都市と農村の食 事メニューの違い, 調查法の差違などがこの理由として あげられた（血中鉛も平均男女各 $5.4 \mu \mathrm{g} / \mathrm{d} l$ と低かっ た)。年秢差，地域差の解析が今後の問題として残され た。

903：Desilva 法て小児, 学童, 青年の混合唾液鉛濃 度を湘定した。測定值はほほ対数正規型の分布を示し， 前 2 群において性差がなかった。鈶濃度に及ほすす唾液の 分泌量と速度，および鉛吸収の指標との関連が今後の研 究課題と考えられた（血奬鉛との相関はある由）。

904 908（325 329頁）座長 友国勝磨（佐賀医大） 904 : 演者らはすでにトリクロロエチレン暴露による ALA-D 阻害につき発表しているが，今回は，鉛とトリ クロロエチレンによる ALA-D 阻害機構の違いについて 追究した。(1)トリクロロエチレン投与中止後の ALA-D 
阻害の回復はどうか，(2)酷酸鉛投与ラットの捸水状況は どうか，(3ラット血液の溶血方法について，等の筫疑応 答がなされた。

905：ラットの肝及び末梢血における ALA-Dの臟器 特異性について多方面から検討したところ，両者には臓 器特異性がなく，同一の醉素であることを明らかにし た。肝と掔における ALA-Dの特異性についてはどうか との質問があり，末検討であると答えられた。

906: 肝と血液 ALA-D $の$ in vitro 鉛阻害に及ほす $\mathrm{Hb}$ の影望について検討し, 血液と肝 ALA.D 活性阻害 の羑異は恐らく Hbの有無によるものであろうと報告し

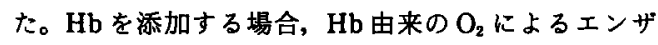
イム SH 基の酸化に基つく ALA-D 活性低下を十分考虑 する必要があるとのコメントがあった (平野)。

907 ：鉛，スス(II)による血中 ALA-D 阻害に対する セレンの修飾作用について検討し，(1)スス(II)による ALA-D 活性阻害に対し, 等モル又はそれ以上のセレン が拮抗する，(2)鉛による阻害に対しては，セレンはスス （II）の場合程著明な拮抗作用は示さない等の点を明らか にした。投与メタルの酸化数, 拮抗の定義等の質問があ つた。

908：ALA-D 活性の紫外部吸光分析法について検討 $し$ ，特にPBGの紫外部測定を行う場合，230-235 mm の波長が適当であること等を明らかにした。ヨーロッパ 標準法とも有意な相関があり，本法の実用性が期待され る。

\section{912（330～333頁）座長 原田 辛（関西労衝衛 生技術センター) \\ 909 : 竹谷らは, ZnPの生成機構を解明するために,} まず $\mathrm{Fe}^{3+}$ を基質とするへム合成系の研究を行い,その 結果, $\mathrm{Fe}^{3+}$ は NAD(P)H,FMN(FAD)によって還元 され, $\mathrm{Fe}^{2+}$ とされ, NAD(P)H酸化系に会合した ferrochelatase によってへム合成が起こるものと考え た。さらにこれに対する鉛の影豐について研究を行い, へム $\left(\mathrm{Fe}^{3+}\right)$ 合成は，鉛によってへム $\left(\mathrm{Fe}^{2+}\right)$ 合成より 強く阻害されることを明らかにし，このへム $\left(\mathrm{Fe}^{3+}\right)$ 合 成活性の鉛に対する鋭敏な感受性は, ferrochelatase お よび NADH 脱水醭素の鉛に対する感受性に由来するも のと推論した。そして ZnP 合成における $\mathrm{nn}$ は，その 反応過程で還元される必要がないため，鉛に対する感受 性が弱いのだと考えた。徳永は,この発表に付加して, $\mathrm{ZnP}$ の生成には, へムが出来る 2 つの $\mathrm{Fe}, \mathrm{Zn}$ の存在, 罢元系に関係する塐素が関与するので, これらを総合し
て考えなければならないとのへ，斉藤は，細胞全体とし て明らかにされるようにという希望をのへた。

910：入野は，酢酸鉛を投与した母マウスの乳汁(鉛を 含む)で, 幼若マウスを出産からずっと育て, 生体中の 鉛以外に銅, Znについても钼察したが，鉛は母マウス を介して急速に乳仔に移行し, 血液, 肝, 大脳, 小脳に おける銅，Zn 含量に影锌があったとのべた。

911，912：野見山は，24羽のウサギを5 群に分け，そ れぞれに酷酸鉛の濃度をかえて静脈内に投与し，生体の 変化, 臓器中の各種金属量などを観案し報告した。その 結果, 量一反応関係があったのは, 赤血球 ALADの低 下, 尿中 $\delta$-ALA, COP の排出增加であり, 臟器中で は, 肝の $\mathrm{Zn}$, 鉛, $\mathrm{Ca}, \mathrm{Mg}, \mathrm{Mn}$ 濃度の增加, 腎皮質 では, 鉛, Coの増加， $\mathrm{Al}$, 銅の低下がみとめられたと 報告した。また肝中の鉛の分子量分布，腎皮質における メタロチオネンについても観察して報告した。

以上 3 題について討議が行われ，910と 912 との肝にお ける銅，その他の動きの相違は，使用動物，使用動物の 使用時期 (生長期には変化が大きい), 観察時期などの相 違からくるものであり,このことから one shot study で明らかにされた事夷は，そのままで作業者にもって行 くことは危険があるという敏告があった。その他動物実 験における動物の問題, 鉛の投与方法, 結果の読み方な どについても議論があり，またもっと重症となれば，生 体反応が異なるものがあるという意見もあった。

913 916（334～337頁）座長 徳永力雄（関西医大） 913 : 表 3 の鉛量の絶対量 (座長質問) は，黄便が量も 多かったが正確な数值は憶えていない（回答)。

914 ：硝酸鉛と酢酸鉛の両化合物を用いた理由(佐賀医 大・友国）およびそれらの影锌の評価（保健衛生大・島） について，両化合物の影整をみる目的でそれそれ MLD の1/6量を与えたが，影整は $\mathrm{Pb}^{++}$の絶対量と $\mathrm{NO}_{3}{ }^{-}$, $\mathrm{C}_{2} \mathrm{H}_{3} \mathrm{O}_{2}$-の複合したものと考えられる。1P以外の投与 法 (座長) は試みていないこと, A・B 群と C 群の違い （同）は，初期では集合細胞の種類が異なることが知られ ておりその違いによること（北里研・鈴木）が追加され た。

915：行動研究用動物の他の育成例およびTHAラッ トの鉛に対する感受性の差の有無（座長）について, 他 に迷路実験用動物の育成例があること， $\mathrm{Pb}$ に対して感 受性の高い群と低い群に分れる可能性が示唆されている が (60年産業街生学会諥演集参昭), 本 strain の確立に よって今後この方面の研究が期待できることが付言され 
た。

916 ：この作業の環境測定のデータの有無(聖マリアン ナ医大・吉田）について，個人サンプリングの湘定值と して吹付作業て $0.129 \mu \mathrm{g} / \mathrm{m}^{3}$, 施細作業 $0.092 \mu \mathrm{g} / \mathrm{m}^{3}$, 焼成作業では $0.078 \mu \mathrm{g} / \mathrm{m}^{3}$, 等となっている由回答され た。釉薬の鉛含量（佐賀医大・友国）は，ノベリティ製 造では鉛含量が高く $25.1 \%$ あある。焼成作業ての乾燥釉 薬粉の寄与が大きいことは, 乾燥してはがれやすく, 運 搬中（肩の位置）経気道吸入が起こりやすいことなどに よるが，他の工場について同様のことがいえるかは別問 題であろう(座長との擥議)。

以上，全般に質問が少なく，せっかくの機会が有効に 活用されていないように思われた。他人の研究もよく䛨 んて，もっと自由な意見交換がなされることが望まれ る。

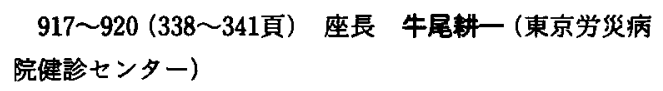

917：四エチル鉛の脱アルキル化につき, 三エチル化 には主として肝が，二エチル化には赤血球が関与すると の成䋖を報告。徳永上り生成量が10\%前後であるのにそ の結論を出してよいのかとの筫問があったが，基質量の 多いin vitro実験であることから演者らの結論は正しい ものと考える。

918 : 講演集発行以後の成續として, 神経束構成線維 の伝夏速度への $\mathrm{Pb}$ の影響の他に, $\mathrm{Zn}, \mathrm{Cu} ， の$ 相互作 用を追加して報告。伝䎡速度の遅い線維では $\mathrm{Pb}$ の影響

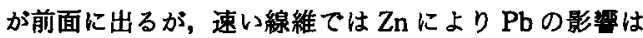
完全に阻止されると。Cuについては言及がなかった。

919：可動員量に対する動員量（CaEDTA $20 \mathrm{mg} / \mathrm{kg}$ ) の比 $k$ を演者らの数理モデルにより算定した。 $\mathrm{Zn} k<$ $\mathrm{Cu} k$ については Znの可動員量が著しく大きいこと，及 び $\mathrm{Zn} と \mathrm{Cu}$ との体内存在様式の相遣の 2 点で説明した。 また血䍊 $\mathrm{Zn}$ は可動員量のよい指標であると報告。山村 より血液 Znの日差変動を採血の際，考虑しているかと の實問があった。

920：演者らの“尿量補正值” は $\mathrm{Hg}$ を除く各種重金属 および有機物質の尿中排泄への尿量変動の影響を最小限 に抑えることが可能である。 $\mathrm{Pb}, \mathrm{Cr}, \mathrm{Hg}$ の “尿量補正 值”は, $\mathrm{Hg}$ の24時間排泄量とともにそれらの体内金属 量をよく反映すると報告。山村は透析での成結から尿 $\mathrm{Hg}$ を血獎 $\mathrm{Hg}$ と parallel に考えてよいのかと質問し た。
921 923 (342〜344頁) 座長 山村行夫（聖マリアン 十医大)

921 ：毛髮中ミネラル濃度は前処理としての洗浄法に よる影轠が大きいものと少ないものとがある。 Na，K は洗浄法による差がとくに大きい。毛鬁中の微量元素を 測る場合，一番重要なことは外因性のものと内因性のも のとがどこで分れるかということである。どのような手 技を用いるのがよいか(慶応大・近藤)。演題418では，落 ちるものは末洗埩，落ちないものは洗净すればよいと言 われたが，個々のミネラルにつき最適な方法を見つける ことが必要なのてはないか（慶応大·近藤）。今は外部污 染に由来したものの残りを内因性と考えている程度にす ぎない。洗净方法により差があるように思われるため， この点についてさらに検討するつもりである（演者）。

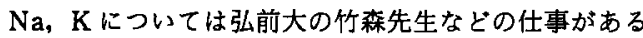
(佐賀医大 ・平井)。

922 : 南米のブラジル・サンパウロ州，ボリビア・サン タクルス州，パラグァイ・イグアヌの3 3 カ国 4 地域の日

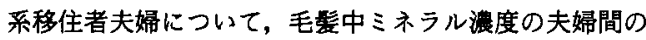
相関性を調へたたものである。結論として，必須元素では 相関性が低く，污染元素には相関性が見られた。ボリビ アの移住者では毛髪中水銀の夫婦間相関は高く，毛彭中 水銀浱度と魚食摄取頻度との間にも相関性が見い出され たと言う。CrからAsまての元素は検出限界以下てあ ったと述べてあるが，これは，ICP の精度が悪かったた めか（聖マリアン十医大・山内）。そうであると思う（演 者)。Na，K は疾病や肥満との関係があったか（保健衛 生大・日高)。疾病は除いてある(演者)。Hg を見るとブ ラジルとボリピアでは相関が高いがパラグァイには相関 がない。この理由はなにか（東北大・渡辺）との質問が あった。

923 : 発育小児 ( $6 \sim 16$ 歳)の毛髮中 $\mathrm{Fe}, \mathrm{Mn}, \mathrm{Zn}$ 濃度 と体格指標との相関性について検討したものである。こ れらのデータは 2 年半, 同一個人を追跡したものである か（帝京大・瀬古）。同一個人を追跡できたのは一部であ った(徳島大・西山)。また，この時期の小児の頭髪中 $\mathrm{Zn}$ 濃度は上昇するように思われるが，一部低下している。 これはどうしてかなどの質問があった。

924〜927 (345 348頁) 座長 吉川 岐阜大)

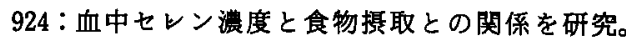
肉・魚・大豆や植物性脂肪の摂取量の多い者ほど血中セ レン湍度が高いという。食品中セレンの分析では，最高

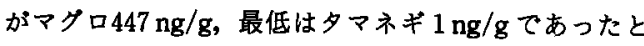


いう。

925 ：覀セレン酸投与による下垂体，甲状腺，副腎皮 質ホルモンに与える影響について検討。亜セレン酸はコ ルチコステロンの合成には作用しないが，放出に影響を 与える。プロラクチンに対しては合成・放出ともに影響 を与えるという。こうした変化は，セレンがストレッサ 一として作用しているとも考えられるがとの筫問に対し て,この点はいまははっきりしないとのこと。

926：要セレン酸が生体内でセレノジグルタチオン (GSSeSG) に代䇅されるが，後者の毒性が前者に比して 著しく強いことを報告。ことに GSSeSG が心筋細胞に 壊死をおこすことは興味がある事実であろう。この GSSeSG は赤血球内でセレンと GSH の存在下で生成さ れる代謝産物である。

927 ：ICR マウスの赤血球には，塩化メチル水銀で溶

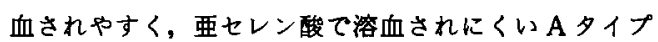
と，その逆の Bタイプとがある。Aタイプの赤血球の $\mathrm{Hb}$ は 1 分子当り 4 個, Bタイプのそれは 6 個の SH 基 をもっている。さらに, AとBタイプの違いは, $\mathrm{Hb}$

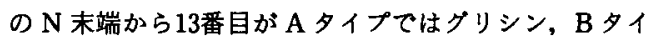
プてはシステインであるという。

928～930（349 351頁）座長 西山敬太郎（徳島大） 928 : 血清及び尿中アルミニウムをフレームレス原子 吸光法で直接測定することを検討し，グラファイト板の 炉内括入, $\mathrm{Mg}$ の添加, コンピューターによる吸収ピー クの読み取りと解析など様々の工夫を行った結果, 精度 よく測定できることを示した。他の臟器も灰化に硫磁を 用いれば干涉が少なく測定可能とのこと。

929：Mnのラット脳室内投与方法としてカニューレ を固定しマイクロシリンジで定期的に注入するよりも， 埋没ポンプで連続的に行う方法が優れているとした。 $\mathrm{Mn}$ 投与後臓器への Mn 分布, 脳各部の DA, NAを測 定したが，アミン類については更に検討したい，ラット に神経症状, 行動異常等は認めなかった。

$930:$ ラット由来の織維芽細胞 (3Y1) の染色体異常出 現に及浪す 6 価クロム $\left(\mathrm{K}_{2} \mathrm{Cr}_{2} \mathrm{O}_{7}\right)$ の影䡈をみた。短期ば くろ (24時間) 及び長期ばくろ（4〜5日おきの継代， 8 〜16継代目) により, 細胞增殖, コロニー形成に変化が ない程度の低濃度 $(0.1 \mathrm{ppm})$ でも染色体異常の出現頻度 の増加がみられた。培地内での $\mathrm{Cr}^{+6} \rightarrow \mathrm{Cr}^{+3}$ については みていない, 長期ばくろにおける量一反応関係は今後み たい,とのことであった。
931 934（533～536頁） 座長 児玉 泰（産業医大） 931：那須らは，水質污濁指標，污濁物留除去を目的 としてアオウキクサによる重金属の吸収と蓄䅡について 研究をわこなっている。今回は，銅とカト゚ミウムの相互 作用について報告したが，とくに preculture が濃度， 葉状体数および温重量に及ほす影響について述べた。

932 ：湯川らは人体藏器 (肝, 大脳, 腎)および毛鬞中 の微量元秦をPIXE 法により分析した結果を報告した。 金属間の相互比，構造等についての情報を得る良好な手 段であるが，試料分析における処理能力および嶩度とし ての表現が可能かなどの質疑がなされた。

933 ：大野らは正常女性, 分婏時の母親, 胎帯から採 血し, 赤血球と血整中の $\mathrm{Zn}, \mathrm{Cu}, \mathrm{Fe}$ 濃度おょび赤血 球中の各酵素活性を湘定し比較をおこなった。金属濃度 には， 3 対象血液で有意の差が認められたが，異常分婏 のときにもこのような動きが諗められるものか否かの質 疑がなされた。

934：内野は, ラットを用い加齢が腎臟中の重金属灌 度に及ほす影響を調へた結果を報告した。対象とした金

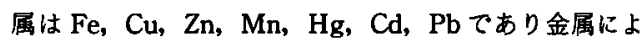
り変化のパターンが異なり $\mathrm{Zn}, \mathrm{Fe}, \mathrm{Cu}$ な゙では雌雄 差が見られた。この性差が認められる理由について筫疑 がなされたが，そのメカニスムは不明であるとの答弁が あった。また $\mathrm{Pb}, \mathrm{Zn} の$ 生後直後の值が高い理由, 剆定 にあたっての污染が考えられないかとの筫問もあった。

\section{5～937（537～539頁）座長 三浦 刢（熊本大）}

935 ：都市居住成人男女の全血中 $\mathrm{Mn}, \mathrm{Cu}$ を測定し, 加齢及び契煙の影锌を明確に喻出できなかった。これに 対し，湘定精度の内部管理の必要性を野見山(自治医大) は強調した。

936：日本猿にCuSO 液を174週間投与し，葴器中金 属を測定，肝中銅の $80 \%$ はW 3 万の蛋白分画に，そ の他はセルロプラスミン (C.P.) 等の蛋白結合銅であっ た。これに対し，血嶈 C.P.の増加機序（東北大・渡辺）, $\mathrm{Cu}$ 投与量の決定方法や触よりの Cu捸取量（保健衛生 大・島）等の質問があり，Cu投与量は渡良瀬川の実際デ ー夕に基き決定, $\mathrm{Cu}$ の䬣中含量は僅少で問題にならず, またC.P.の増加機序は不明であるという。

937 ：銅欠乏食投与ラットでは尿中の蛋白, アミノ酸, 糖の一過性增加, 血慗 Al.P.tase とセルロプラスミンの 低下がみられた。これに対し，この種の欠乏食実験での 合成食調製の困難さが強調された。なお葴器の組織学的 変化は今後精查するとのことである。 
938 942(540 544頁) 座長 正吾(保健衛生大) 938，939：荒川らは，ジブチル錫の抗䭪鹪用を検討 し，4種の担癌マウスについて程度の差はあるが, 明ら 加に life spanの増加を認め, 又病変初期における高濃 度投与は，かなりの有効性があることを指摘した。

又, 同氏らは，マウスによるカラゲナン浮腪法によ り，有機鍟及びハイドロコーチソンによる抗炎症効果を 検討し、ことに同法第 2 相に扣いて抑制作用を認め, 又, 本反応が量一依存性であることを明らかにした。な お,この種の有機錫による免疫応答に対する生体影響に ついては, 今後の検討課題とした。

940 ：大谷らは，ヨウ化三フエニル錫の経口投与実験 により，家鬼に高脂血症を惹起せしめると報告した。こ れに対して，(1)過酸化脂質の変動が大きいこと，(2)測定 法として鉄の除去等の処理について質疑があった。

941：平田らは，八ムスター肝葴における七素化合物 の新和性を, in vivo で検討し, 4 種の化合物のうち As （III）の親和力が強く, As (III) は, 蛋白と結合して, 毒 性発現の一因となることを明らかにした。

942：山内らは，トリメチルヒ素（アルセノベタイン） を八ムスターに経口投与し, 尿, 基便中への排泄パター ンを検討した。アルセノべタンは，大部分が尿中に排 泄され，その過程において生体への毒性は，ほとんどみ るものがないとした。又, TMA も畫便への排泄は極め て微量であると報告した。

943〜947（545～549頁）座長 堀口俊一（大阪市大） 943，944：地下水は飲用水としても用いられるのか (座長) に対して，飲用と雑用と両方である (演者) との 答えで，人体への取り込みもあることが分った。944て $\mathrm{Ni}$ が測定されている理由 (座長)について, 発がん性に 着目した（演者）とのことであった。島（保健衛生大） から，本研究を行った意図などについて補足説明がなき れた。なお，944も「自然界における」と題した理由(座 長) に対して，タバコの菓の污染を考えて (島) との答 があった。

945 : 次の訂正があった。（図 1 の $\mathrm{x}$ 軸は $4,8,12$, $16,20 \mathrm{ng} / \mathrm{m} l$, 図 2 の $\mathrm{ng} / \mathrm{mg}$ は $\mathrm{ng} / \mathrm{m} l$ に訂正)。図 3 の PFC と血中 Be 浱度のプロットは低浱度長期投与 群と高流度短期投与群の両方とも高くなるのか（聖マリ アンナ医大・坂口）に対して，個々にプロットすると高 灌度群は図 3 の右に分布し，低湿度群は左に分布する (演者)。時間の検討について（坂口）に対して, 高浀度 群は 4 週でも死亡するので, それ以上は無理, 低瀑度群
は10週，12週で投与中止したが，できればもうすこし長 い検討を加えたい（演者）とのことであった。中村（聖 マリアンナ医大）加図 $2 て ゙ ， 2$ 週で差がなく，4週で これだけ差が出てくる理由についての質問に対して, Be は早く排泄されるか, それが追いつかない(演者) と の返答がされた。島（保健衛生大）加ら, cellmediated か humoral かに関して, 前者のみてはないと 云えるとの追加がなされた。また全身影響について，七 トでは慢性べ肺があるが，似た変化が起こったか(座長) に対して，腹空内投与で長く持たせたときには肝 granuloma ができる (島) との答えであった。

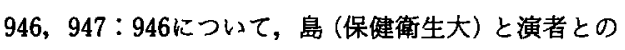
間に質疑応答があり,島から今回の実験では, 結論が Cuの方にいってしまったが,ここでBeの影腤につい て suspectするなら, Fig. 1のプロットを職種別に検討 してみてはどうか, また14名と小人数の作業場では各々 の作業をまわり持って行っている可能性があるが，作業 状況の把握により, 高潭度曝露者とそうでないものとが 出てくると思われるので, Fig. 1 は補正できると考え る旨の発言があった。さらに島から，Beの補体系への 影響と考察で述へられているが，もう少し実験をつめな いとそういえぬではないか。Beだけでなく，化合物に よって金属の性質は大きく変わり，とくに Be の場合は その特異性が大きく変わるので, 䈌密な検討を要すると の発言もあった。947について, Fig. 1 の結果はきれい なデータだが,この種の実験では細胞自体の生存期間の 十分な把暒がベースにないと問題であるので補正を加え た方がよい。とくに肺由来細胞では Beによる低下なの か, 細胞の生存期間が短いのかを考える必要がある(島) に対して，実験前にBe を入れない場合の細胞の生存期 間について模討したが，たしかに細胞数の低下は認めら れた。しかし，その下降が一番みられないということで 3 日という期間を選択した（演者）とのことであった。

\section{950（550～552頁）座長 谷息一嘉（日本大）}

948 : ニッケルの発癌研究の一環として, ニッケルに 感受性の高い胸腺細胞を用い, ニッケルのリソゾーム醉 素に対する影䚀を調べた。結果は，3.0 mg/100 gBW の投与で体重の若干の低下と胸腺および脾葴重量の著し い減少が見られ, 胸腺のリソゾーム活性が増大すること を示した。今後の研究の方向について, ニッケル投与に よるリソゾーム活性の増大とニッケル発癌との関連性に ついて明らかにしていくと述へた。この外に, 酢酸ニッ ケルを使用した理由について貿問が出た。 
949，950：この演題は，ニッケル化合物粒子のラット への吸入暴露実駼 $1 \sim 5$ の内 2 題である。949は長期 ( 1 年）間にわたって安定した吸入暴霞条件を得るための技 術的㭘討てあり，950は 1 年間の暴露後におけるニッケ ルの肺内沈着量と他の眮器内崄度との関連についての発 表であった。討論は残り 3 題発表後の総合討論に㜔つ た。

951 953（553〜 555頁） 座曼 西住昌裕（佐賀医大） 3 題とも $\mathrm{Ni}$ 化合物粒子のラットへの吸入暴露実験に 関するものである。

$951 ： \mathrm{NiO}$ を吸入させた場合と NiS を吸入させた場 合の臟器中 $\mathrm{Ni}$ 湛度, 肺内 $\mathrm{Ni}$ 沈着率を比較したものて あるが，1力月間のほほ同一の暴露条件下で $\mathrm{NiO} て ゙ は$ 肺内沈着率が高く, 他䐬器への移行がみられないが,
NiS 暴露では肺内沈着率が著しく低く，肝・堅・血液に も高㴤度の Ni が検出されたことを報告し，溶解度の差 による所が大であると述へたた。

$952: \mathrm{Ni}$ 化合物粒子の吸入により, 肺のリン脂實量, レシチン, ケファリン, レシチンの脂肪酸組成を調ヘた もので, 投与算度, 投与期間, $\mathrm{Ni}$ 化学形態て程度は異 なるが，リン脂筫量ならびにその棈成成分の堌量を報告 した。な扔暴露中止後は対照群のレベルに近つくこと，

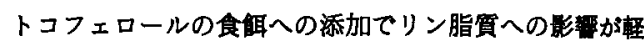
減されることも示した。

$953: \mathrm{NiO}$ 粒子の 1 ケ月吸入によるラット肺の病理組 織学的所見では, Ni 粒子は肺胞内大食細胞に存在し， 暴麗直後ではクララ細胞，II 型肺胞上皮細胞ならびに Tubular Myelinの増加がみられ, 暴露後20ヶ月放貫し た群で末梢肺腺息 1 例がみられたとの報告があった。 